\title{
The Strategies in the Battles and Struggles of Prophet Muhammad: How It Can Be Applied in Modern Business
}

\author{
GholamReza Zandi ${ }^{1}$, Naser Zandi Pour Joupari² \& Ayesha Aslam³ \\ ${ }^{1}$ Graduate School of Business, SEGi University, Malaysia \\ 2 Department of Management, Rafsanjan Branch, Islamic Azad University, Iran \\ ${ }^{3}$ Scholar, SEGi University, Malaysia \\ Correspondence: GholamReza Zandi, Associate Professor Dr., Graduate School of Business, SEGi University, \\ Kuala Lumpur, 47810, Malaysia. Tel: 60-3-6145-3148. E-mail: zandi@ segi.edu.my
}

Received: September 23, 2015

Accepted: September 28, 2015

Online Published: October 26, 2015

doi:10.5539/ibr.v8n11p84

URL: http://dx.doi.org/10.5539/ibr.v8n11p84

\begin{abstract}
The main purpose of this study is to investigate the strategies of Prophet Muhammad PBUH in wars and struggles, and how they are practiced now in contemporary businesses and organizations. This study is interested to read the biography oh Prophet Muhammad, the strategies which He made during wars and migration, their execution and consequences and how modern businesses adopt these strategies to improve the organizational graph. The purpose of this paper is thoroughly study the biography of beloved Prophet and to recall the Holy Prophet (PBUH) strategies, which He used during his life and mostly implemented in wars and battles for victory. The concept of making strategies is came from Him, which now world widely followed by everyone even by Muslims or not Muslims. Prophet presented the thought of environmental Analysis, for the purpose to get information from external and internal environment about enemies. This analysis is applicable upon all organizations especially Military. Now it is executed as risk management, to prevent from sudden unfortunate events in future. In short, all the strategies, which are now run-through all organizations are basically belongs to Holy Prophet
\end{abstract}

Keywords: Prophet Muhammad strategies, war and struggles, business

\section{Introduction}

\subsection{Background of the Study}

This study is concerned with the strategies battles and struggles of Prophet Muhammad and how they can be applied in the modern business setting. Consistent with the objective, the research draws on two research literatures that have been rarely integrated, the strategies in strategic management research and biography of the Prophet (Sirah). From Islamic perspective, there is a lot to be learnt from the strategies used by the Prophet in his 23 year of struggles to establish Islam in the Arabian Peninsula. It is, therefore, necessary and important to bridge the gap in order to empirically address the research question.

Strategic Management is an essential function in any organization. It has been touted as one of the effective management tools in strengthening organization performance through effective decision making and systematic strategic formulation and implementation (Smith, 1994). Strategic management has been defined by various authors in different ways. Dess and Eisner (2008) for example define it as comprising analysis, decisions and actions that an organization undertakes to create and sustain competitive advantage. Thompson, Strickland, and Gamble (2008) define strategy as competitive moves and business approaches to grow the business, attract and please customers, compete successfully, conduct operations and achieve targeted levels of organizational performance. To David (2009) strategic management is the art and science of formulating, implementing and evaluating cross functional decisions that enable the organization to achieve its objectives. There are many similarities in these definitions of strategic management with the focus on planning. Executing and evaluating organizational results over the long term.

The literature related to campaign and battle strategies of Prophet Muhammad is still sparse. Higher learning 
institutions are lacking of reference sources. They rely heavily upon the Western management research and theories, especially theories and models emerging from the USA and Europe (Ali \& Camp, 1995). Thus, this study is undertaken to fill this knowledge gap.

\subsection{Problem Statement}

The need to Islamized knowledge including strategic management in particular was stressed by many Muslim thinkers such as Iqbal, Mawdudi, Abduh, Al-Faruqi, Al-Attas, Taha Jabir Al Alwani, and Mona Abul-Fadl started in the early of 20th century (Mumtaz, 2010; Mohamed, 2009). Raziuddin Siddique recognized the Muslim philosopher and revivalist, Muhammad Iqbal as a pioneer of the idea of the Islamization of knowledge based on his Persian poem, mathnavi (Traveller) in early 1930's (Mumtaz, 2010):

"When the Arabs spread their wings in Europe Knowledge and science were given a new foundation one fruit of the seed that desert dwellers had planted was plucked out by Europeans Happy are those who "Islamized" it... This fairy is from the bottle of our ancestors

Capture it again because it comes from our mountains.

Azhar Kazmi (2003) stressed the need of empirical research in Islamic management includes Islamic strategic management. He writes (Azhar, 2003):

"Granted that there is a lack of interest among scholars in research on Islamic per perceptive on management studies and that the existing literature on the subject presents a disappointing scenario, one needs to be clear about what measures are necessary to rekindle interest in such research ..."

$\mathrm{He}$ further observed: Research work in Islamic perspectives on management studies is scarce. The work available does not serve to propagate further research work, as it is mostly descriptive and not analytical. Purposeful qualitative work could become a fountainhead of meaningful quantitative research but it is largely missing presently."

At present, there has been almost no systematic attempt to link the practice of strategies of Prophet Muhammad in his struggles and battles to convey Islam and he practices of strategies in the modem business.

\subsection{Research Objective}

The overall objective of the study is to identify the specific Prophet Muhammad's strategies in his campaigns and battles that have been outlined by the Al-Quran, Hadith, and Islamic literature and compare these with Western literature to determine similarities and differences to modem business strategies. More specifically the objectives of the research are:

1) To identify the specific Prophet Muhammad's strategies in his campaigns and battles

2) To compare the Prophet's strategies with modem business strategies

3) To provide ground for developing Islamic strategic management in the future studies

4) To determine which strategies can be used in business context

5) To examine which strategies and to what extent the Prophet Muhammad's strategies are being implemented by managers/owners of SME in strategizing their organization.

6 To determine whether the organization that implements the Prophet's strategies perform better than the organizations do not implement the Prophet's strategies.

These objectives provided the basic framework and focus of the study.

\subsection{Research Questions}

The study seeks to address the research objectives through the examination of the following research questions:

1) What were the specific strategies that the Prophet employed in His campaign and battles?

2) What and how Islamic world view, philosophical and epistemological grounded on the Prophet's and Islamic strategic management?

3) How do the strategies of the Prophet compare with present day business?

4) Which of the Prophet's strategies are used by the SME managers/owners?

5) To which extent the Prophet Muhammad's strategies are being implemented by managers/owners in strategizing companies? 
6) To what extent do these strategies affect the performance of the companies?

\subsection{Scope of Study}

The study will be done in two stages. The first stage is to explore the strategies that the Prophet used his campaigns and battles. This will be done through reviewing the Quran, Hadiths, and Sirah, classifying the strategies and attempting to measure them. What is discovered from the Quran, Hadith, and Sirah (biography of the Prophet) will be compared with the Western literature on strategic management particularly on business strategies. This report will focus mainly on this part.

The second stage of the research will be to verify these strategies from Muslim scholars as well as Muslim businessmen. This will be followed by pilot tests of instrument and empirical tests on about 200 SMEs in Malaysia.

As the study tries to add value and insight to the strategic management from Islamic perspective in Malaysian context, the research will be conducted in Malaysia on account of; (1) Muslim is a largest community and workforce in the country; (2) Malaysia would be a role model of practicing Islamic strategic management in multi-religion and multi-cultural society; (3) the need of more number, in-depth and quality studies of Islamic strategic management in the local context, and; (4) to promote greater understanding between globe culture and citizen .

\subsection{Significance of the Study}

This research is a standout from other previous studies in Western and Eastern strategic management namely Alexander the Great, Ludwig von Mises, Sun Tzu's Art of War, Ancient Thai, Miyamoto Mushahi's (Pheng, 2001). It explores in-depth the major areas of strategic management particularly in the Prophet's struggles and battles based on Al-Quran, Hadith, Islamic and Western literatures.

Thus, there is a requirement to re-evaluate the contemporary strategic management practices through the lens of Islamic paradigm as its current practices incline merely to fulfill the economic dimension of needs and wants. The other dimensions such as fulfilling the religious obligation, social and moral needs have not to be neglected.

Accordingly, the boundary of current strategic management needs to be extended from positive to normative strategic management (Khalifa, 2001) which operates under tawhidic paradigm. This area has the element of fix and change under Islamic rulings spirit and paradigm in terms of its vision, objective, implementation, evaluation, control and ethics as well. Besides, the Muslim strategist as ulul-albab (the intellects) has to hold the Islamic worldview in whole and not to be stucked in a part of religion such as fiqh, hadith or tafsir per se which bound to lead to inconsistencies and misconception. To operationalize strategy, the hikmah is utilized in which the rational thinking is guided by revelation. All in all, it is expected that this study to be among the pioneer study which attempts to develop new concept, construct and dimension to the area of Islamic strategic management.

The study establishes the strategic management concepts from Islamic perception paradigm and worldview which encompasses its philosophy, principles, practices and ethics. Philosophical ground, as the essence, will be given attention as it laid the foundation of the subject. It is not merely making the 'external' changes and adding a few Quranic verses and hadith in appropriate place to explain strategic management phenomena. With its limitation, however, this study is to address the issue of epistemology rather than methodology (Mumtaz, 2010).

It deconstructs some of the modem Western concepts; construct the Islamic concepts on it and linking the missing link between both paradigms. As Kazmi (2003) preferred that the researcher averts the "superimposing theories developed from the Islamic revealed knowledge sources on to conventional organization. The study, however, with its critical perspective, does not intend to pretend the Islamic strategies at the expense of modem Western strategies as both of paradigm an co-exist side by side.

The expected finding will highlight the relevance of Islamic Strategic Management concepts and approaches and notes its similarities and differences. It is hoped to make a modest contribution to the corpus of literature available on the current strategic management. This research would become an important reference for future studies pertaining to the Prophet's strategic management practices. An introduction to the Prophet's strategic management is an initial attempt to provide managers with an additional way of strategizing their organization.

\section{Literature Review}




\subsection{Introduction}

This research explores in-depth the major areas of strategic management particularly from the biography of the Prophet based on Islamic classical and modern sources and Western literatures and providing empirical evidence as well. To date, there is no known empirical study that has been conducted on the lines similar to this study.

The Western scholars especially the orientalist have made valuable, and in many instances critical, contributions to the understanding of Islam in non-Muslim contexts; even so there is no evidence of an orientalist being interested in management studies. Orientalists came as response to the need of western scholar to understand Islam; they could have been interested in Islamic perspective on management studies but so far few scholars had taken the lead (Kazmi, 2003).

Management, particularly strategic management is a discipline of study and research that has been promoted and researched largely by the Americans and Europeans. The issues in research leading to theory building have come from a cultural context that is mainly Anglo-Saxon and Judea-Christian (Kazmi, 2003).

From Western perspective as proposed by such writers as Dess, Lumpkin, and Eisner (2008), Thompson, Strickland, and Gamble (2008) and David (2009) came up with processes and strategies that have been found to be effective. David (2009) for example suggests that the process of strategic management may be divided into three stages: Strategy formulation, Strategy implementation, Strategy evaluation.

These stages may have components of their own: Strategy formulation starts with determining vision and mission statements for the organization, followed by analysis of the external environment and analysis of the internal environment. Long term objectives have to be determined followed by generating of strategies and selection of strategies. Once the strategies have been decided, implementation will take place. This stage requires the mobilization of resources of leadership, human capital, money, raw materials, machines and systems and procedures. Once implemented the strategies have to be evaluated with regards to their effectiveness; should there be any short coming. They have to be addressed.

The starting points of strategy are teemed in ancient military. The lexis of strategy rooted from 'strategos', a Greek word which stands for 'the art of a general'. Many authors integrate the notions of strategy and military or politics such as Clausewitz, Hegel, Kant, Liddel Hart, Montesquieu, Shakespeare, and Tolstoy. Furthermore, the authors such as Bismarck, Hitler, Machiavelli, Napoleon, and Yamamoto were represented the militarists and politician theorist (Bracker, 2000). According to Bracker (2000), the earliest modern author connecting the notion of strategy and business were Von Neumann and Morgenstern (1947) via theory of games. Later on, many other authors followed their footsteps in combining both fields.

There is some compatibility between business competition and military warfare. First, both businesses and armies strive for a favorable position by defeating their rivals while defending themselves. Second, both organizations must be well organized and managed. Third, both require strategies and tactics. Fourth, the leadership of both an army and an enterprise has an important influence on shaping of success. Fifth, they both need high quality and committed people. Finally, they both thrived on information. But there is a fundamental difference between business and war: the former is an act of construction, the latter an act of destruction. The two are diametrically opposite in reign (Chen, 2004).

The writings of Sun Tzu of more than 2500 years ago still ring true today. Some excerpts may serve as useful reminders:

War (competition) is of vital to the state (organization). Thus it deserves to be studied thoroughly, Warfare is based on deception; if near, make it appear you are far away, if you have big numbers make it appear you are small; hold out bait to enemy, etc.

Carter et al. (2010) proposed the interdisciplinary approach of studying strategy; incorporating strategy and sociological domain which concerns of performativity and authority. They state that accounting and organization disciplines derive more from sociology than industrial economics, which was claimed the strategy stemmed from.

Johns and Doren (2010) conducted an empirical study to explain in what way a business is able to execute competitive intelligence into the business planning.

Chatterjee (2009) attempted to broaden the perspectives of business in divulging their potentials for accomplishing integrative managerial viewpoints. He suggests amalgamating value of main ideas of Indian classical literature and representing their relevance to the contemporary business. Consequently, the classical 
Indian literature such as Arthashastra written three millennium BC by Kautilya Chanakya. Ramayana and Mahabharata epics, Bhagvad Gita and Vedic should be referred.

\subsection{Empirical Literature}

The previous work is relatively few in numbers of empirical researches was done to find the association between Sun Tzu and business and strategic management in particular. The few empirical research used a case study approach with a very limited of businesses and locations. For instance, Dezi Chen, Hongji Chen, Chow Hou Wee, Daiping Hu, and Fanghua Wang (2009) undertook an empirical research to examine the seven elements of Sun Tzu, which function as indicators for determining the competitiveness of the business organization. The gross sale and operational profits serve as measurement of company earnings.

They mentioned the seven elements. Re-structured to eight and weigh against them to present setting: (1) The moral law unity in a business; (2) Heaven vs. political and economic milieu; (3) Earth vs. resource of company growth; (4) The commander vs. business leader; (5) Method and discipline vs. Business organization and management structure; (6) "Military equipment' vs. technological advantage; (7) "Battle unit" vs. whole personnel excellence; (8) Reward and punishment vs. motivation in company. As a result, Dezi et al (2009) proposed that Sun Tzu's business competitiveness analysis model, which contributes an inventive strategic process to businesses and enhances strategic management model. Furthermore, it augments research on the business application of art of war.

Wang and Chang (2009) research argues on suitability of 'Porters five forces as a guide to strategy and entrepreneurship in China and presents a new "five forces" model based on Sun Tzu's strategic acumen. The new five forces are business purpose, location; climate, organization and leader are show to ascertain business success in the present complex and exigent setting. They endeavored in liberating the business from the tenet of "Porter's five forces" which was initiated in the past three decades and recognizing the new decisive factors of success in contemporary setting.

Foo (2007) proposed the new; epistemology of strategy which composes other disciplines and ancient text into strategy. Some disciplines for instance psychology, sociology and politics are not fully tapped in the process of making strategy. On the other hand, the strategy in companies is heavily relied on business related disciplines such as accounting, marketing and economics. He suggested the Chinese epistemology of strategy which hiding in ancient text such as sun Tzu Art of War, Tao Te Ching, and Romance of Three Kingdoms has to amalgamate into current strategy. He contends, often the culture and contexts has to take the part altogether.

Pheng and Hong (2005) did empirical study helps to induce construction firms to view the strategic quality management (SQM) through lessons from Sun Tzu's Art of War. Whereas, Guoquan Chen (2005) highlights the need to establish combination of cross-cultural organizational learning system model especially based on western and Chinese management thoughts. He introduced the model which contain of nine amalgamated organizational learning comprising "discovering, importing. Selecting, executing, transferring, reflecting, acquiring knowledge from environment. Contributing edge to environment and building organizational memory". He explained and analyzed the evidences from Chinese classics texts including The Analects of Confucius, Book of Change, Tao Te-Ching, The Art of War, and Chuan-Xi-Lu.

Wann Yih Wu, Chih Hsiung Chou, and Ya-Jung Wu (2004) conducted an empirical research to evaluate the relationships of Sun Tzu's codes of situation appraisal, strategic implementation, and strategic control. In addition, the degree of implementation of Sun Tzu's codes of situation appraisal, strategy implementation, and strategic control influence on an organization acquisition its essential success factors. Their results show that the utilizing of Sun Tzu's principle on situation appraisal, strategy implementation, and strategic control are positively correlated.

IP and Koo (2004) did case study utilizing a fusion of the balanced scorecard, SWOT analysis and quality function deployment produces a practical method for managerial and consultant practitioners to transform equivocal strategy into action. Sun Tzu's Art of War is further integrated to extend a more organized strategic formulation structure.

Thomas K. Y. T. (2002) examined the doctrine of Chinese military theorists which are well-known for their military operation in ancient China, Liu Tao and Shan Lue in developing management doctrine of a company in Hong Kong, the Powerhouse of Hong Kong Productivity Council, "Three strategies and their focus". The objectives of Powerhouse are to form an icon for Hong Kong as a regional service center; to create a style of service productivity and service quality; and to enhance capability via the growth and stretching of good service 
practices. This research attempted to recognize the area that Powerhouse should develop namely; customer focus, process focus, human capital, innovation capital, power leadership and power performance.

Teck and Grinyer (2010) did the empirical research to examine the association of Sun Tzu and strategic thinking among managers in ASEAN which includes Thailand, Philippines, Indonesia, Malaysia, and Singapore. The researchers use the various of variables such as (1) Reason for strategic approach (e.g. goal oriented culture, industry competitiveness, in light for strategy formulation, coping with change); (2) Organizational attributes (e.g. organic or strategic planning, bureaucracy in strategic planning process, planning at divisional level. (3) Technocracy in strategic planning (e.g. gathering information, utilization of forecasts and techniques, mapping and formalization of strategies, control and monitoring of performance. technology and structural of planning; (4) Critical success factors (e.g. environmental scanning, strategic thinking, ensuring adequate resources and CEO strategy behavior); (5) Generating strategies; (6) Environmental factors and formulating strategy; and (7) Resources for strategy. This is comprehensive research in strategic thinking in associating the Sun Tzu literature; however, it does not cover the other areas of strategic management such as strategic choice, implementation and feedback.

Pheng and Fang (2005) study looked into the routines of lean in the construction industry and the resemblance of lean construction tenet and Sun Tzu's strategic tenets. The study suggested that the strategic tenet divided by Sun Tzu be utilized for the advance development of lean tenets a divided by Sun Tzu.

\subsection{Non-Empirical Literature}

The non-empirical research on Sun Tzu especially books grows intensively in 1990 but the downturn trend started in 2010s with the same researchers working on it such as Gagliardy, Kheng-Hor, Michaelson, and Michaelson.

One of major stream of research is linking Sun Tzu with general business strategies and strategic management. Michaelson and Michaelson (2010) outline and present the strategies in the light of Sun Tzu to be employed by managers to outperform the competitors. Some strategies highlighted are built a good organizational structure, coordinate momentum and timing, utilize extraordinary force, getting mental advantage, preventing the leadership mistakes, estimate the situation, choose a favorable battlefield, know yourself and rivals, be disruptive and intrusive, invest in intelligence resource and practice counterintelligence. The literature discusses the typical ideas and principle of Sun Tzu's strategies in business context yet it provides the relevant examples of current business applying the strategies.

Kheng-Hor (2008) covers most of strategic management areas in the light of Sun Tzu. He reviews, for instance, a few approaches in applying Sun Tzu in business, planning, know yourself, people management, internal analysis including human resource, operations, productions, research, marketing, accounting and finance; office politics, management information system, strategy formulation process, strategy implementation and evolution of management theories. The literature explains the way of application of Sun Tzu principles through a few current management theories and approaches especially the psychology and organizational behavior make it distinct from others.

Another comprehensive and details literature on linking the business strategic management and Sun Tzu was conducted by wee. Lee and Hidajat (2002). The literature encompasses the situation appraisal, formulation of goal and strategies, evaluation of strategies, the human and operational factor of implementation of strategies and strategic controls.

In the similar vein, Chalak (1993) accomplished another comprehensive study of strategic management and its relation to Sun Tzu. The analysis covers planning, costing, maneuvering, tactics, business development. Apart from it, Hean-Tatt (2003) studied the same phenomenon, the business strategy and leadership and their relationship with Sun Tzu thirteen sections. The study covers strategic planning process, "7-S" qualities in total management leadership, competent leaders and employee, Crisis management, feedback and control, operational management.

The analysis of the possible strategies and tactics to be employed by project manager in the context of construction project management using Sun Tzu was done by Pheng (2001). Apart from Sun Tzu, he analyses the same subject from Lao Tzu, Zhuge Liang, Thirty-Six Chinese Classical Strategies, Tao Zhugong, Miyamoto Mushahi's book of Five Ring and Ancient Thai Battlefield's perspective and interpretation. The study has captured the linkages between modern business strategies with the ancient military and non-military texts.

Another dimension of utilizing Sun Tzu strategy to increase profit, win customers and succeed in business was 
done by Michaelson and Michaelson (2011). They suggest the importance of offensive strategy, focus on employee flexibility, simplicity, focus on strengths, strategic alignment the organizational objective and employees, communication, resources and uniting team. The literature covers strategic planning, implementation and a little aspect of control and evaluation.

The analysis by Chia (2005) to associate business and Sun Tzu by presenting many brief case studies of business and it's related to Sun Tzu. The study brings the case of Wal-Mart, Dell, IKEA, Microsoft, McDonald's, RFID, Apple, Samsung and Hello-Kitty! As the study presents many cases which resulted the blurring discussion.

The study which relationship of competitive managers and Sun Tzu's strategy was accomplished by Gagliardy (2007). As his normal methods of study in this area, he presents the translation of Sun Tzu text followed by line-by-line analysis and interpretation of the phenomenon. It covers the element of analysis the situation, controlling, planning, process innovation, problem and opportunities, internal politics, continuous improvement, the work environment and acquiring information. Gagliardy gave a number of new sights regarding of becoming a competent managers using Sun Tzu's strategy.

The likewise study to link business strategy with Sun Tzu was performed by Gagliardy (2004b). As the study quite comprehensive and covers many aspects of strategic management including strategic formulation, implementation and control. Some elements introduced are managing innovation and creativity, change management, organizational strengths and weaknesses, competitive attitude, dealing with uncertainty and the failure of analysis. The disadvantage of this work is, it contain not in-depth analysis as its try to study many strategic management phenomenon in union.

The second major stream of research linking the Sun Tzu with marketing strategies. For instance, Michaelson and Michaelson (2004) discuss developing marketing strategies draws the idea from Sun Tzu. They outline twelve principles to succeed in marketing campaign such as respect the customer, managing the intelligence, human resource and other resources; surprise and offensive strategy, leadership, simplicity, obtain safe position. Manoeuvre, economical operations and upholding the marketing objective. They offer sound interpretation of Sun Tzu in the marketing strategies perspective though they introduce the typical points and ideas highlighted by Sun Tzu and its management interpreters.

The another endeavor to analyze and relate Sun Tzu and designing the marketing strategies and tactics was performed by The third stream of research links Sun Tzu and strategies of dealing with conflict. Gimian and Boyce (2008) analyze the strategy and tactic of converting chaos and conflict into success in personal life and organization using the philosophy of Sun Tzu, for instance the concept of interconnectedness, holistic thinking, conflict, victory and applying the 'universal energy' (shih). The researchers include fourteen eddied to reflect the action to be taken in managing the problem. The literature discusses the subject in Taoism perspective thoroughly and this rarely done by Western management researchers. As greater focus given to explain the Taoism worldview in the subject, the literature lack of practical perspective.

Huynh (2011) provided spiritual framework in dealing with conflict in inner self, family and organization. He has suggests employing spiritual approach in avoiding conflict before it manifest, addressing manifested crisis fast and serenely, using intelligence and benevolence, turning enemy into friends and controlling emotion. The element of spirituality to counter conflict, which is highlighted in this literature, it is not obvious as it not much different to other non-spirituality literatures.

The fourth stream of research linking Sun Tzu and career success in organization. Krause (2005) explains the strategies can be employed by executives to gain competitive advantage in the career and organization. He suggested the idea of adopting the planning, competitive actions and strategy, good position to survive, taking good opportunity in right time, effective control, assessing competitive situations and causes of failure, offensive strategy, attacking reputation and gathering intelligence. The literature covers the adapting of Sun Tzu strategy in the perspective of employee which aims to succeed in the organization.

The literature to evaluate the effective strategies to be employed inside the organization to address the organizational politics through Sun Tzu strategy (Kheng-Hor, 2004). The literature focuses in dealing and handling the competition among the staff of the organization. It reviews the strategies of dealing with the suspensors, subordinates, peers, unscrupulous politics, the advantage of networking and women in organization dominated by man. The literature offers the strategies for competition from intra-organization perspective instead of typical inter-organizations perspective.

The other streams of research are linking Sun Tzu and investment and linking Sun Tzu with general management. 
Yong (2003) discuss the strategy and tactic of property investment in Malaysia context. He analyses the relationship of effective property investment with Sun Tzu principles for instance the affiliation of property investment and war, detailed planning, effective information, effective net and property investment strategies. Even though the author gives brief explanation. He offers the sound strategies in real estate investment utilizing Sun Tzu's principle as the strategic management area is lacking of this type of literature.

\subsection{Western Literature on Strategy}

Current writers on strategic management for example David (2009), Dess et al. (2008), and Thompson et al. (2008) are agreeable that a strategic management system begins with the formulation of strategies followed by implementation and evaluation of results. The strategy formulation stage includes determining vision and mission statements, external and internal analysis, long-term objectives, and generation of strategies and selection of appropriate strategy. The implementation stage covers determining the annual plan and objectives, budgeting, functional plans, leadership and change, organizational structure and Management information systems. The third stage is the evaluation of result and taking corrective actions.

There are several strategy levels in practice within organizations. The most common typology of strategies being: (corporate level, business level), functional level and operational level. Corporate level strategy refers strategy at the group level for multiple companies belonging to a group: This strategy describe that the companies in group are supposed to follow. The divisional (business level strategy refers to strategy prepared for a particular business in a specific industry. Functional Strategies are to support business strategies prepared for various departments marketing, manufacturing, human resources, finance, research and development, etc. The upper level of strategy is the operational which includes strategy for plant managers, sale manager, production managers and other department managers.

David (2009) suggests the following types of corporate strategies: Integration strategies, intensive strategies, diversification strategies and defensive strategies. Integration strategies cover strategies intended to control either raw material or channel of distribution. They can be categorized as forward integration which is to increase ownership or control over distributors or retailers; backward integration which is to gain ownership or increased control over suppliers. Horizontal integration is a strategy seeking control over competitors. Mergers, acquisitions, takeovers are meant to achieve control over the market.

Intensive strategies refer to market penetration, market development and product development. These strategies require intensive effort to improve the company's competitive position. Market penetration seeks to increase market-hare for present products and services by for example increased advertisements, promotion or increased publicity. Market development involves making the firm existing product available to new markets, while product development means the strategy of increasing ale by improving or modifying present products or services.

The next type of corporate strategy is diversification strategy. There two types of diversification: Related or unrelated. It is related diversification when the firm's value chains have cross-business strategic fits, otherwise they are not related. In related diversification businesses can transfer, combine, share activities because they are similar. In this process they achieve synergy. In unrelated diversification no synergy can be expected, only financial results.

The last type of corporate strategy is called defensive strategy which includes retrenchment, divestiture and liquidation. Retrenchment takes place when an organization consolidates in order to cut costs to halt declining sales and profits. It is also called turnaround strategy. Divestiture is done by selling a division or part of an organization. It is done to raise capital for redeployment. Liquidation refers to selling all or in parts for their tangible worth.

\subsubsection{Porter's Generic Business Strategies}

Michael Porter $(1980,1985)$ suggests that at the business level organizations that want to gain competitive advantage have to choose from three possible strategies: Low cost leadership, differentiation and focus. Cost leadership derive advantage from using standardized product at very cost per unit for price empitive consumer Differentiation provide advantage by producing products to fulfill the needs of consumers who want unique product and are willing to pay for them. Focus strategy refers to producing products for a small (niche) group of customers either by way of low cost or differentiation and fulfilling them in the best possible manner.

\subsubsection{Strategic Alliances}


Western literature has produced some research into strategic alliances whose concept is to have collaborative arrangements between two or more companies to achieve mutually beneficial strategic outcomes (Thompson, Strickland, \& Gamble, 2008). A strategic alliance is a formal agreement to jointly contribute resources, share risk, share control and mutual dependence.

\subsubsection{Merger and Acquisition}

Mergers and acquisitions are useful tools diversification and vertical integration and strategic alliance cannot quite fulfill it. A merger is a pooling of equals with the newly established unit taking a new identity (Thompson et al., 2008). An acquisition takes place when a firm purchases and absorbs the operation of another company. These strategies are meant to increase cost efficiency, to expand its geographical market, to gain market here, to reduce competition, and to gain access to new technology.

French (2009) investigates the epistemological options for strategic management. The literature in the field is influenced by closed systems method; a Modernist (scientific) and Cybernetic system method. This method is pertinent where in long-term forecast is probable. He contends that other epistemological options predominantly critical management studies and complex self-adapting systems have chance to expand the comprehension for strategic thinking. In complicated and fast changing surroundings, long-term forecast is not practical. Closed systems are embodied by equilibrium and open systems are embodied by an exchange with their surroundings (Von, 2009). He revealed the option of implementing open system thought into strategic management.

French (2009) mentioned the inexorableness for strategic academics to re-think the schools classifications and rationalize their theories of strategic behavior, considering that strategy is a modernist notion. But modernism may not introduced epistemology for the progress of strategic thinking in which business are comprehended as intricate elf-adapting systems.

Calof (2008) analyses cross disciplinary literatures which accentuates the versatile role which competitive intelligence engage in a modern organization from practitioner, academic and inter-disciplinary viewpoint. Competitive intelligence being an activity contain predominantly of environmental scanning and strategic management literature. Competitive includes the compilation of information, internal, external and from competitors, but also from customers, suppliers, technologies, environments, and potential business relations. It is devised to help forewarning and assist to forecast the actions of competitors, customers, and government, not just the competition (Gilad, 1996; Calaf, 2008).

As outlined by Gilad (2006) well-matched and complimentary fields which surrounds the domain of intelligence are "risk assessment, intelligence estimates; war gaming; scenario developments (and); state gate analysis; blind spot laundry; management assumptions; blue ocean opportunities; proactive asymmetric strategy; and early warning". The new area of research and activity are quickly becoming component of the advanced intelligence structure. The terms of peripheral vision, corporate radar, weak signals, business insight, foresight, competing on analytics, and knowledge management use similar terms to those used in the competitive intelligence literatures.

The interesting argument is with regard to management and organization literatures, there is a long tradition of inter-disciplinary and cross-referencing between different literatures such as sociology, philosophy, ethics, cultural studies, psychology and the political sciences.

Pech and Slade (2005) explored the Manoeuvre theory in business dimension. Manoeuvre theory, which originally invented as military battle doctrine was depicted as a military strategic and tactical doctrine of planning and action utilizing surprise, speed, and save of effort. It has capacity to offer alike accomplishment for business strategy as it has for military strategy. They envisaged that the utilizing of this theory will produce a more vigorous environment and will amplified competitive conduct. They assert that Manoeuvre entails flexibility and choice.

Pech and Slade (2004) describe a prescriptive method for the business to implementing its strategic intent. It discusses the hands-on planning phase's adapted military admiration procedural. They argue from a military dimension using the examples from both military and business areas. The study emphasizes the need for absorbent, elastic and fast planning process, delegated decision-making and high levels of business capacity, initiative, entrustment, and personnel capability.

Grattan (2004) did a case study on diaries of military leader, Alan Brooke to shed light on the ideas of strategy formulation method in business discipline. The diaries contain of proves strategy formulation can be weigh against to theories of business strategy. The method is evaluation of Alan Brooke (military leader and Winston Churchill (political leader) character and strategy, and draw on the data in the diary and the structure of business 
strategies invented by Mintzberg et al. The analysis is elucidating the way strategy is extended in an actual setting and is also shows the value of the comparative method to the research of strategy method. Furthermore, the merit of this method is the verification of the world wideness of strategy formulation methods.

\subsubsection{Theoretical Background of the Study}

This study employed Michael Porter's Five-Forces Model to serve as its theoretical background. The model explains the five forces that shape the developing of any business strategy which includes the potential entrants, buyers, suppliers, substitute products and competitors (David, 2009; Pearce \& Robinson, 2009; Thompson et al., 2008; Porter, 1979).

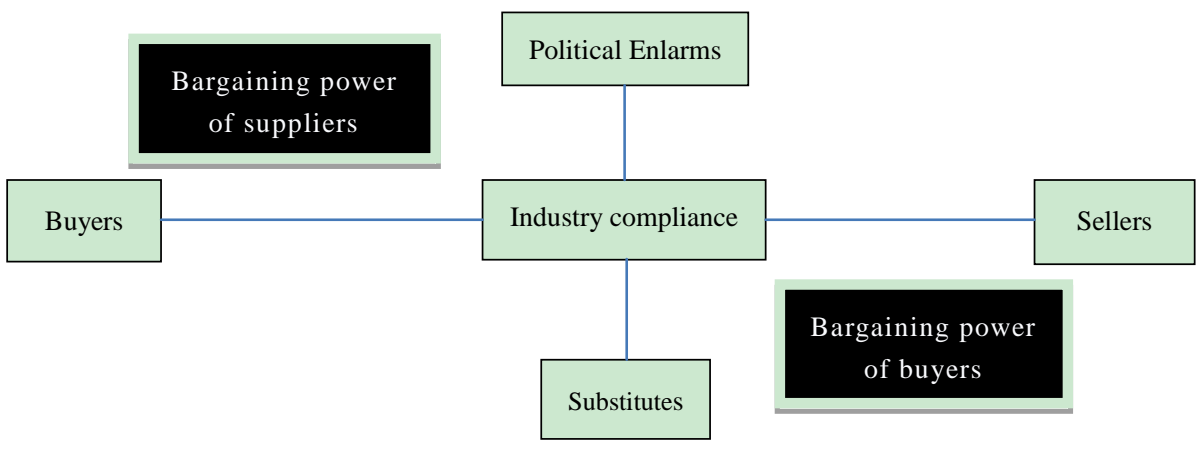

Source: Porter (1980).

The extended rivalry that results from all five forces defines an industry's structure and shapes the nature of competitive interaction within an industry.

\subsection{Introduction}

Scholars have produced a great deal of works in the area of Biography of the Prophet. The strategies in the wars and battle of the Prophet Muhammad constitute one of the major themes of the discussion. Despite its importance, research on the Prophet's strategies is relatively recent phenomenon the literature is still sparse and with non-empirical nature. There is not known empirical study has been conducted on this study. As an early study in these two disciplines of knowledge namely, the biography of Prophet and strategic management the researcher employed the conceptual research. A thorough study of the life of Prophet Muhammad recalls the effective strategic thinking and planning (Khaliq \& Fontaine, 2011). The researcher can learn from the lessons of the past and build on them. While developing strategic kill for the modern era (Ahmad \& Fontaine, 2011). There is increasing trend in managers of management beyond the modern management schools to include ancient ones such as Sun Tzu Art of War. Nevertheless, little attention is recently paid to the Islamic management approach that far outperformed more than its contemporaries, and all left indelible marks on the minds of innumerable researchers, leaders and managers (Jabnoun, 2005).

This research explores in depth of the major areas of strategic management particularly the Prophet's battles and wars based on Islamic classical and modern sources and Western literatures and providing empirical evident as well. The Western especially orientalists have made a valuable, and in many instances a critical, contribution to the understanding of Islam in non-Muslim contexts, even there is no evidence of an orientalist being interested in management studies. Just as orientalists came as response to the need of Western scholars to understand Islam, they could be interested in Islamic perspective on management studies provided scholars take the lead (Kazmi, 2003). Management, particularly strategic management is a discipline of study and researched that has been promoted and researched largely by the Americans and European. The issues in research leading to theory building have come from a cultural context that is mainly Anglo-Saxon and Judea-Christian (Kazmi, 2003). A critical comment to a number of the attempt to study the strategies in Sirah (the biography of Prophet); these strategies are universal and eternal. However, the researcher's attempts at their interpretation and application reflect the exigencies of the time and place in which this attempt was made.

\subsubsection{The Literature on Strategies in Sirah}

The subject of the Prophet's biography (Sirah) contains the principles of strategy and has been much quoted in recent years in the business context. The following is a review of some relevant literature. The strategies of the Prophet were identified after a thorough analysis of several authentic books on the biography of the Prophet, 
namely: A biography of prophet of Islam in the light of the original sources: an analytical study (Ahmad, 2005); The noble life of the Prophet (As-Sallabee, 2005); Ar-Raheeq al-makhtum (the sealed nectar) (Mubarakpuri, 1996); Muhammad at Medina (Montgomery, 1988); and Muhammad: his life based on the earliest sources (Lings, 1983). Besides, the secondary sources especially in form of books were employed as an aid in identifying the strategies and served as compliment to the primary sources. The books are namely: Jejak biasness rasul: Peribadi biasness Muhammad bin Abdullah (Mohamed \& Aizuddinur, 2010); Strategic planning and implementation for Islamic organizations (Beekun, 2006); The Prophet's diplomacy: The art of negotiation as conceived and developed by the Prophet of Islam (Iqbal, 2009); Al-madrasah al-nabawiyah al-askariyyah (Faris, 1993); Battles by the Prophet (Rizvi,1992); Durus askariyyah min al-sirah al-nabawiyyah (Mahmud, 1990); Muhammad as a military leader (Rahman, 1990); The battles of the Prophet of Allah (Vol. 2) (Ahmed, 1986); The Prophet's concept of war (Ahmed, 1986) and; The battles of the Prophet of Allah (Ahmed, 1985); The Prophet's Strategy for Islamic revolution (Israr, 2008).

The Prophet stressed the value of planning throughout man of his event of life. He recognizes the value of vision and mission that is to spread Islam to all over the world (Mubarakpuri, 2009). Mohamed Sulaiman Aizuddinur Zakaria (2010) have attempted to study the strategies of Prophet throughout his life during war and peace. Afzal Iqbal (2009) attempted to study the Prophet's diplomacy during the war and peace. He has done an interesting and instructive study of an aspect of the Prophet. He has analyzed many situations with which the Prophet faced in his life time in order to place his approach in its proper perspective. He has shown conclusively that because the Prophet strategy in peace and in war was superb in conception and execution it before paid the richest dividends in terms of human welfare. Ali Muhammad As-Sallaabee (2005) did extensive research on the life of the Prophet and did thorough analysis on lessons from most of the events, wars and battles of the Prophet. At the same year, Mahdi Rizqullah Ahmad (2005) did the extensive and analytical research and narration of the Prophet life. Safrnrranman Mubarakfuri (1996) gave significant contribution towards the literature of biography of the Prophet through his famous book, Ar-Raheeq Al-Makhtum (The Sealed Nectar). Meanwhile, Ameenul Hassan Rizvi (1992) was conducted narration and analysis of circumstances, which led to the eight battles, the state and stage in which the Islamic organization at the time of each battle was and how the consequences of each battle affected and benefited the work of Islamic organization. Watt (1988) attempted to do research on this subject from Orientals perspective. He tried to be fair to Muslims while investigating and analyzing the facts in Islamic tradition. Afzal ur Rahman (1980) embarked an early Eco to introduce a new approach to the life-study of the Prophet which presents the Prophet military leader and shows the effectiveness of his leadership and strategies. He examine how prophet led his men through hardship of war and adversity and won complete to gain tall his rival and established the excellent landscape of peace, goodness and justice for the first time in the Arabian Peninsula in less than a decade.

Beside all of these books and researches, there are a number of literatures of management from Islamic perspectives that are useful in exploring the strategies of the Prophet in the battle and wars. Among them are Khaliq Ahmad and Rodrigue Fontaine (2011) gave at certain extent the input of lessons of biography of the Prophet. Beekun (2006) in his work, Strategic Planning and Implementation for Islamic Organization touched in brief on strategies of the Prophet in battles and wars. Meanwhile, Jabnoun (1994) did an extensive study management in the Islamic perspective. Even he did not give a significant contribution on the strategies of the Prophet; at least he added some inputs on this subject.

\subsection{The Strategies of Prophet Muhammad in Sirah}

\subsubsection{Vision and Mission}

The Prophet's vision for Muslims: To seek the pleasure of Allah (the ultimate goal of Muslim). One who receives Allah's pleasure will be rewarded with Jannah (Paradise). Paradise is explicitly painted in the Quran as a place of abundance in the Hereafter where there are trees with streams underneath. On the other hand one who transgressed will refer in Hellfire.

According to Abu Huraira the Prophet said he righteous will receive such excellent rewards in the Hereafter that no eye had ever seen, nor ear had ever heard, nor a human heart had ever think of.

His mission:

- To call upon human being the religion: Islam (peace and security).

- To raise the religion of Allah and eliminate all forms of polytheism.

- To maintain the peacefulness in the country and on the earth of Allah. 
- To do preparation to intimidate the challenge of Allah and their alliances.

To wage war upon the challenger: If there is no other mean to attain peacefulness.

The Prophet through the Quran and Hadith taught Muslims Tawhid (belief in Allah, the one and only God), belief in the Prophets, belief in the angels, belief in the holy books, belief in the Day of Judgment, belief in Qadaq and Qadar (Allah decides what your destiny will be). This set of beliefs is a must for the Muslim.

Tawhid is the quintessence of Islam, without it there is no Islamic civilization, culture, strategic management, purpose of life and no Islam. It's an integral constituent of Islam which unites all its parts into a whole and harmonizes the relationships among them (Al-Faruqi \& Mumtaz, p. 127).

\subsubsection{Environmental Analysis}

Wheelen and Hunger (2008) define environmental analysis is the monitoring, assessment, and dispersal of information from external and internal environments to key people within the organization. It is critically need be analyzed organization including the military organization led by the Prophet. In Ghazwah Badr 17th (Ramadhan 2H), the Prophet asked a young boy the number of camels slaughtered by the enemy, (Quraisy) per day. The boy replied on the first day 9 camels and second day 10 camels were slaughtered. The Prophet estimated that their enemy had about 900 to 1000 soldiers. This shows the Prophet had used intelligence to gather information on the enemy.

\subsubsection{Strategic Choices}

\subsubsection{Speed}

There is ample evidence throughout the Prophet history implemented the speed strategy in his military campaign. In accordance with the conclusion of McNeilly (1996) that this strategy is widely applied in business and military. Besides, there are many references maintain it is significant strategy in current companies. Speed is a crucial strategy in war and business as it gives advantage to those have it as it leave the rival in confusion and the competition may be finish before they can react. In business, speed means time reduction, reduce the time of making decision, developing product (Michaelson \& Michaelson, 2011), responding to Customer Speed offers capability to exploit market 1 (Pech \& Slade, 2005) fore to the point, speed is associated with effectiveness which is needed in any competition. Conversely, a word of cautious, the preparedness and well-planned is indispensable in attacking the rival as impromptu and unprepared attack cause surprise, squander resources and made rival understand their strategy and tactics (McNeilly, 1996).

An exemplar of consequence of this strategy is in Ghazwah Khaibar (Muharram, 7H), the Prophet and Muslims moved very fast toward Khaibar as their competitor; Khaibar Jews, did not notice it and they screamed, "Muhammad coming, Muhammad coming!. Prophet moves very fast as 160 kilometers within 6 days and the competitor alliance, Bani Ghatafan do not have opportunity to help them (Fazlur, 1990).

In Ghazwah Badr (Ramadhan, 2H), Muslims used difficult route via mountains to reach Badar faster than their enemy and control the water (resources) and strategic location. (Fazlur, 1990).

In Ghazwah Uhud (Syawwal, 3H), in order to gain time-based competitive advantage, Muslims used difficult route via mountains to reach Uhud faster than their enemy and control the strategic location (Fazlur, 1990).

Ghazwah Dumat Al-Jandal (Rabi'ul, SH), Muslims moved very fast toward Dumah al-Jandal. The place was close to the frontier of Syria and about 15 or 16 days journey from Madinah (Fazlur, 1990) to shows the endurance and speed with which Muslim force could move to distant places.

Ghazwah Bani Mustaliq (Zil Qa'idah, 5H), the Prophet force reached Muraishi in a very short time.

Ghazwah Bani Quraizah (Zil Qa'idah, 5H), the Prophet asked the companions to move fast and ordered them to pray Asr prayer at Bani Quraizah. They moved to fast but they were unable to reach at Bani Quraizah at Asr. They reached it at early night. This is due to the place is quite far. The Prophet's goal is to apply the fast strategies to ensure the rival cannot do preparation to counter the Muslim attack. Ghazwah Al-Hudaibiyah (Zil Qa'idah, 6H), Muslims changed his route to Makkah when he knew Quraisy tribe ready to launch an attack toward them and the Prophet reached Makkah without noticed by their enemy/ (Fazlur, 1990).

Ghazwah Khaibar (Muharram, 7H), Muslims moved very fast toward Khaibar as their enemy; Khaibar Jews, did not noticed it and they screamed, "Muhammad coming, Muhammad coming! Prophet moves very fast as 100 miles within 6 days and the enemy alliance, Bani Ghatafan do not have opportunity to help them (Fazlur, 1990).

Ghazwah Tabuk (Rajab, 8H), Muslims moved very fast toward Tabuk as their competitor did not expect that the 
Prophet can reach toward Tabuk as that fast (Fazlur, 1990).

Ibn 'Aun reported: I wrote to Nafi' inquiring from him whether it was necessary to extend (to the disbelievers) an invitation to accept (Islam) before making them in fight. He wrote (in reply) to me that it was necessary in the early days of Islam. The Messenger of Allah (peace be upon him) made a raid upon Bani Mustaliq while they were unaware and their cattle were having a drink at the water. He killed those who fought and imprisoned others. On that very day, he captured Juwairiya bint al-Harith. Nafi' said that this tradition was related to him by Abdullah b. Umar who (himself) was among the raiding troops (Sahib Muslim).

\subsubsection{Surprise}

This study recognized that the surprise strategy became one of important strategy in his military campaign. The Prophet recurrently take advantage of this strategy to make his competitor fright, shock and ill-equipped.

Leveraging the unexpected can produce a competitive advantage (Pech \& Slade, 2005). Surprise has different shapes for assaulting the competitor at unpredicted times, serendipitous force, astonishing strategically, tactical or plain Manoeuvre. It involves the astonishment of point in time, location, material and weapon. The constituent of surprise are confidentiality, innovation, creativity and swiftness 1 Pech and Slade. Kaab bin Malik said that "Whenever the Prophet decided on any battle he usually kept the object secret and did not clarify it." Whereas, in Ghazwah Khaibar, he closed his ears and invoked, O God, close their eyes and let them not see us until they are upon them" (Rahman, 1980).

In Ghazwah Bani Mustaliq (Zil Qa'idah, 5H), this sudden appearance of the Muslim force surprised the rival and they dispersed in fear and confusion. The rival dispersed in fear and confusion. However, the rival dispersed in fear and confusion. However, the leader of Banu Mustaliq, Harith bins Abi Dirar. But they were routed in the very first attack after losing 10 of their men; the rest were taken prisoner along with their animals and possession.

Ghazwah Khandaq (Syawwal, 5H), used trench, a new tactics which never been used by local competitors. This tactics used in foreign country.

Ghazwah Banu Libyan (Rabi'ul Awwal, 6H), when the Prophet left Madinah for Banu Libyan, he acted as if were marching towards Syria in order to surprise Banu Libyan.

Ghazwah Khaibar (Muharram, 7H), the Prophet reached at unexpected time and location. Khaibar Jews did not notice it and they screamed, "Muhammad coming, Muhammad coming! Prophet moves very fast as 100 miles within 6 days The Prophet scored another tactical victory over his enemies when he intercepted and intervened between the Bani Ghatafan and Khaibar and stopped the former from Madinah, he camped at a place called Raji, between Ghatafan and Khaibar. When the Bani Ghatafan, came to know of the movements of Muhammad's forces, fearing for the safety of their women and children, they went back and changed their plans of helping the Jews against the Muslims. This ingenious move by Muhammad stopped two allies from joining together to fight him in the expedition of Khaibar (Michaelson, 2010). Ghazwah Tabuk (Rajab, 8H), the Prophet reached at rival base at unexpected time and location. Ibn 'Aun reported: I wrote to Nafi' inquiring from him whether it was necessary to extend (to the disbelievers) an invitation to accept (Islam) before making them in fight. He wrote 'in reply) to me that it was necessary in the early days of Islam. The messenger of Allah (May peace be upon him) made a raid upon Bani ul taliq while they were unaware and their cattle were having a drink at the water. He killed those who fought and imprisoned others. On that very day, he captured Juwairiya bint al-Harith. Nafi' said that this tradition was related to him by Abdullah bin Umar who (himself) was among the raiding troops (Sahih Muslim).

\subsubsection{Strategic Innovation}

The Prophet encouraged and welcomed the innovation in maintaining the organizational competitiveness. The Prophet introduced few innovations in his strategy. In the Battle of Al-Ahzab (Confederates) War (Syawwal, 5H), whereby the Muslims made a ditch or trench is evidence of this strategy as the leader of Alliance Force from Quraisy, Abu Sufyan surprised when the big trench and said: "By the name of Allah, this strategy was never known by the Arabian people." (Rahman, 1980).

As-Sallabee mentioned that to fight in rows is a new ways of fighting in Arab. Allah said: Verily, Allah loves those who fight in His Cause in rows (ranks) as if they were a solid structure (Quran, 61:4). The Prophet's sent a number of his staff; Urwah bin Mas'ud and Ghailan bin Salamah to Jordan to have training on making the more advanced weapons on that time in Jordan such as Ar-Radat (stone thrower ). Ad-Dabbabah (to crush the fortress), 
Al-Manjanik (stone thrower which bigger than Ar-Radat.

\subsubsection{Strategic Alliance}

The theme of strategic alliance materialized in number of occasion. It is a partnership for a certain period of time whereby the partner. $O$ trite their strength and resources to the undertakings and to deal with the threat (Peter \& Robinson, 2009). The result of combining the strength of another panel is gathering the force which will force the competitor the outcome of challenging through organization. For instance, he allied with Jews alliance with Uyainah bin Hisn in Ghazwah D IJandal in Rabi'ul Awwal, SH (As-Sallabee, 2005). Nevertheless, the strengthened the force, not having the alliance is better than having the awful alliance range-Hor. 2008; (McNeilly, 1996). In this case, the Prophet was cautious in choosing the alliances-.The principle of strategic alliance was touched in the Quran: Allah said: "And if they (enemy) incline to peace, you inclines to peace, you incline to it as well, and put your trust in Allah. Surely He is Most Hearing, Most Knowing." (Qur'an, p. 61)

0 Prophet (Muhammad)! Strive hard against the disbelievers and the hypocrites, and bears against them, their abode is Hell, and worst indeed is that destination. They swear by Allah that they said nothing (bad), but really they said the word of disbelief, and they disbelieved after accepting Islam, and they resolved that (plot to murder Prophet Muhammad) which they were unable to carry out, and they could not find any cause to do so except that Allah and His Messenger had enriched them of His Bounty. If then they repent, it will be better for them, but if they turn away. Allah will punish them with a painful torment in this worldly life and in the Hereafter. And there is none for them on earth as a Wali supporter, protector) or a helper (Quran, pp. 73-74).

\subsubsection{Joint Venture}

Joint-venture is an expansion strategy when a company agrees to work together with another company in order to start a new business or enter a new market or diversify. Pearce 11 and Robinson (2009) defined joint venture, a strategy wherein two or more companies create a co-owned business for their more benefit. On the other hand, they warn that the strategy frequently limit the discretion, control and profit of partners. Ghazwah with local tribes regarding the blocking of the cornrnercial route of the Quraish. The ground for joint venture was mentioned in the Quran: Allah said: "And if they (enemy) incline-to peace, you incline to peace, you incline to it as well, and put your trust in Allah. Surely He is Most Hearing, Most Knowing.” (Qur'an, p. 61).

0 Prophet (Muhammad)! Strive hard against the disbelievers and the hypocrites, and be harsh against them, their abode is Hell,-and worst indeed is that destination. They swear by Allah that they said nothing bad), but really they said the word of disbelief, and they disbelieved after accepting Islam, and they resolved that (plot to murder Prophet Muhammad) which they were unable to carry out, and they could not find any cause to do so except that Allah and His Messenger had enriched them of His Bounty. If then they repent, it will be better for them, but if they tum away, Allah will punish them with a painful torment in this worldly life and in the Hereafter. And there is none for them on earth as a Wali (supporter, protector) or a helper (Quran, pp. 73-74).

\subsubsection{Guerrilla Strategy}

There is obvious indication of employment of guerrilla strategy especially when the Muslims not in strong condition, while they were in early phase in Madinah. During that time, they just occupy the new ground. This strategy is well catering the weaker organization to face the well-equipped resources organization (Michaelson \& Michaelson, 2011; Levinson, 1993).

This type of strategy is to challenge the bigger enemy or competitor. In Ghazwah Abwa' (Safar, 2H), the Prophet compete with bigger competitor. That is Quraisy. In Ghazwah Buwat (Rabi'ul Awwal, 2H), he once again attached Quraisy. In Ghazwah Zul-Ushairah (Jamadil Ula, 2H), the expedition aimed to prevent Quraini business delegation which is moving toward Syria. The Qur' an mentions the importance of people in organization and reminded us that a smaller and better quality the more source sometimes outperform the larger human resource; Allah said: “... How often i. mall group overcame a mighty army by Allah's grave?” And Allah is with A -Sabirun he patient) (Quran, p. 249). In another place, Allah commanded: "O Prophet (Muhammad! Cage the believers to fight. If there are twenty steadfast persons amongst you, they will Overcome two hundred, and if there be a hundred steadfast persons they will overcome a thought and of those who disbelieve, because they (the disbelievers) are people who do not understand (Quran, p. 65).

\subsubsection{Turnaround Strategy}

Turnaround strategy was put into practice by the Prophet in the occasion of leaving Makkah, his hometown as his organization does not has needed competencies and capabilities to compete in Makkah. Then he found 
Madinah as a new potential ground for his dakwah (calling) in the Battle of Uhud (Syawwal, 3H) after many Muslims were killed, the remained Muslims chased the enemies in half way to show their high spirit in spite of suffering of defeat. At the end, the Prophet sent Ali to follow tracks of the enemy and to find out where they were and in what direction they were heading. The Prophet gave these instructions to Ali: "Go out and follow the tracks of the people (that is of the enemy). and what they are doing and what they want. If they are steering (i.e.. not riding) their horse and riding their camels, they are returning to Makkah. And if they are riding their horses and steering their camels, they want to go to Madinah. And by the One who has my soul in His hand, if Madinah is what they want, I will go to them and fight them." Ali later recounted, "I then followed their tracks in order to see what they are doing. (and when I caught up to them I that) they were steering their horses and were headed towards the direction of Makkah," Ali then went back and informed the Prophet about what they.

The next day after the battle of Uhud, he called out his staff and ordered them to march to encounter the rival of Muslim. They marched to Harm' Al-Assad, about 8 miles from Madinah. They encamped there for more than 3 days. This news was known by rival, but they fear to fight the Muslims and returned to Makkah. The Prophet invaded Harm' Al-Assad. Later, they patrol, attack and invade the number of places which are close to Madinah to show that they still have the strength to fight their rivals (Mubarakpuri, 1996; As-Sallabee, 2005).

More to the point, the Prophet regularly scrutinized the security situation in changing military environment and movement in the vicinity of Madinah. Another way of risk management, the Prophet for all time he leave Madinah city, he appointed a leader who is responsible of the town general affairs and manage the security of its remained population such as women, children, the sick and the old. He did not leave Madinah defenseless. (Mubarakpuri, 1996).

In $(\mathrm{lH})$, the Prophet has to leave his own market as the market has been captured by rival because his organization does not have needed competencies and capabilities to compete in Makkah market. Then he found Madinah as a new potential market for his calling.

\subsubsection{Offensive Strategy}

It has been said that the best defensive is to attack. The offensive strategy is one the most repeated strategy that was employed by the Prophet. In order to achieve organizational vision and mission of expansion companies have invade the rivals' territory when opportunity permits (Heang-Tatt et al., 1997; Kheng-Hor, 2008).

The offensive is a superior strategy as it can shape the competitor as the offensive group understands their goal and objectives in the first place (Michaelson \& Michaelson, 2011; Kheng-Hor, 2008). They can assault and retreat at their will. The leader is able to design the plan and choose the target. Whenever the operation incoherent with the pre- planned of war, he may choose to revert his team and reduce the loss of tangible and intangible assets. Swiftness and secrecy are significant constituents of this strategy. When the rival is caught in astonishment in offensive assault, they tend to be in off-balance, bewilderment and make mistakes (Hean-Tat et al., 1997).

The Quranic verses: Allah SWT said: Fighting is made obligatory for you (to fight against aggression) even though you dislike it. But you may hate a thing which is good for you, and love a thing which is bad for you. And (remember) that Allah alone knows (all these things) but you do not know." (Al-Qur'an, p. 216).

Allah SWT said: Fight against them so that Allah will punish them by your hands and disgrace them and give you victory over them and heal the breasts of a believing people. And remove the anger of their (believers') hearts. Allah accepts the repentance of whom He wills. Allah is All- Knowing, All-Wise. (Quran, pp. 14-15).

0 Prophet (Muhammad)! Allah is Sufficient for you and for the believers who follow you. Prophet (Muhammad)! Urge the believers to fight. If there are twenty steadfast persons amongst you, they will overcome two hundred, and if there be a hundred steadfast persons they will overcome a thousand of those who disbelieve, because they (the disbelievers) are people who do not understand (Quran, pp. 64-65).

0 you who believe! When you meet those who disbelieve, in a battle-field, never turn your backs to them.

And whoever turns his back to them on such a day-unless it be a stratagem of war, or to retreat to a troop (of his own), he indeed has drawn upon himself wrath from Allah. And his abode is Hell, and worst indeed is that destination! (Quran, pp. 15-16). 0 you who believe! Fight those of the disbelievers who are close to you, and let

them find harshness in you, and know that Allah is with those who are the Al-Muttaqun (the pious). (Quran, pp. 123).

March forth, whether you are light (being healthy, young and wealthy) or heavy (being ill, old and poor), strive 
hard with your wealth and your lives in the Cause of Allah. This is better for you, if you but knew. (Quran, p. 41).

This strategy is most employed by the Prophet in the latter stage in Madinah, after he accumulated strength:

In Ghazwah Bani Qainuga' (Syawwal, 2H), as they found out that the Prophet was marching towards them, they shut up in their fortresses. The Prophet the surrounded and siege them and imposed upon them a siege that lasted for 15 nights. Then they unconditionally surrender to the Prophet (As-Sallaabee, 2005).

In Ghazwah Bani Sulaim (Syawwal, 2H), as reports came of the gathering of the tribes of Bani Sulaim and Bani Ghatafan (Syawwal, 2H) with intent to attack Madinah, the Prophet proceeded with a force of 200 men to stop them. When he reached their watering place, called Al-Kudr,, he found the place was emptied, for the enemy had fled on hearing of the arrival of Muslim force.

In Ghazwah Ghatafan (Rabi"ul Awwal, 3H). The Prophet marched with a company of 450 men when news came of the tribes of Banu Muharib (of Banu Ghatafan) to attack Madinah. The enemy fled before they met.

In Ghazwah Buhran (Jamadil Ula, 3H), report came that a strong force of the tribesman of Banu Sulaim from Buhran was advancing on Madinah. The Prophet advanced towards Hijaz with a force of 300 men and went as far as Buhran, a mine in the area of Hijaz, but the tribesmen fled in panic and he returned to Madinah without fighting.

In Ghazwah Bani Nadhir (Rabi'ul Awwal, 4H), the reasons that prompted the Prophet to attack the Banu Nadir tribe and to expel them from Madinah are they blatantly violated many articles of their treaty with the Muslims. Second, they planned to assassinate the Prophet. They planned to drop a huge stone on him from on top of a wall under which the Prophet was seated. Muslim army marched towards them. The Prophet ordered for their date-palm trees to be burned down. It is a strategic move, because it was their main wealth. They began to lose hope and leaded to their defeat.

In Ghazwah Zatul Riga' (Rabi'ul Thani, 4H), A reports came to the Prophet that the people of Anm'ar and Tha'labah were mobilizing their forces to attack the city. The Prophet marched with a force of 400 (or 700) and advanced as far as Zat Al-Riga and found only womenfolk left there, for their men had fled to mountains.

Ghazwah Last Badar (Sya'ban, 4H), When leaving Uhud, leader of enemy, Abu Sufyan had challenged the Prophet and promised him another encounter at Badr. The Prophet stayed at Badr for eight days but Abu Sufyan went back to Makkah from Al-Zahran. He said to his people that it was a year of famine, so they should return. Surely, a year of plenty and prosperity would suit them better. The Prophet also returned without fighting.

Ghazwah Dumatul Jandal (Rabi'ul Awwal, 5H), the leader of Dumat Al-Jandal often troubled Muslim trading caravans and created a nuisance in the area. When the Prophet heard the news of some tribesman gathering at Dumat Al-Jandal and cruelly treating the camel riders and intending to attack Madinah, he set out with a company of 1000 of men.

In Ghazwah Mu'tah (Jamadil Awwal, 8H), Muslims want to take revenge on Rome due to Rome has killed the Prophet's messenger Al-Harith bin Umair Al-Azdi who was killed by Syurahbil bin Amru Al-Ghassani, governor of Balqa', a territory of Rome.

Ghazwah Fathu Makkah (Ramadhan, 8H), the Prophet's army entered the city from all four corners. The Prophet entered Makkah from its upper end, at Azkhar, ahead of his green squadron. Khalid bin Al-Zubair bin A-Awwam entered at the left flank, Kudan. Meanwhile, Sa'ad bin Ubadah entered from upper-Makkah, paving the way for the entrance of the Prophet. The only resistance offered was at the lower end, where Khalid was corning at al-Khandamah.It was led by Ikrimah bin Abi Jahl, Safwan bin Umayyah and Suhail bin Amr. During that brief and limited fighting, three fell martyrs, but thirteen were killed from the side of the Quraisy.

Ghazwah Tabuk (Rajab, 9H), the Prophet did not encounter any resistance so he returned to Madinah after he stayed in Tabuk for twenty nights. The effect of this invasion is great as regards extending and confirming the Muslims influence and domination and confirming the Muslims influence and domination on the Arabian Peninsula. It was quite obvious to everybody that no power but I lam' would live long among the Arabs.

\subsubsection{Defensive Strategy}

This type of strategy was seldom used by the Prophet Muhammad except during the early stage in Mecca and in Madinah when they were still weak. The defensive strategy was rarely adopted by the Prophet after the Khaddar battle. It could be that it was because this strategy was commonly associated with the weak and incapable 
origination.

Al-Qur'an recorded the application of defensive strategy in Khandaq (Ahzab) War: Allah said: "When they came upon you from above you and from below you, and when the eyes were blurred (due to fear and confusion) and hearts leapt to your throats (due to fear), and you were imagining vain thoughts about Allah." (Al-Quran, pp. 10-11).

In the following Quranic verses, Allah said: "And when a party of them said: "O people of Yathrib (Madinah)! You cannot stand much longer (against the enemy attack!) Go back! And a band of them sought the Prophet's leave (to return), saying: Truly, our homes are exposed," whereas they were not defenseless; they only wished to flee (from fighting for Islam). And if the enemy had entered from all sides into the place where they were, and had they been roused to rebellion against Islam, they would have surely rebelled. And they would have surely rebelled. And they would not hesitate except only for a little while. Although before that they had sworn to Allah never to turn their backs in the fight (on the battle field), and (remember) an oath to Allah must surely be answered for (concerning its fulfillment).Say (0 Muhammad): "Whether you flee from death or from being slain, flight will not profit you-for even though you are safe now, then you would enjoy this word only for a little while." Say: Who can protect you from Allah if it is His will to harm you? Or (who can prevent Him if He) wants to show you mercy?" And (remember) they (the hypocrites) shall find none besides Allah any protector or helper. Allah well knows those of you (hypocrites) who hold other back. And those who ay to their comrades: "Join our side... while they themselves take part in battle just for a little while.

They think the Confederates have not withdrawn. Indeed if the Confederates should come again, they would wish they were in the deserts among the wandering Arabs asking news about you. However, even if they were there with you (at that time), they would take but little part in the fighting." (Al-Quran, pp. 13-20).

There are demands for defence in certain situations such as in fragile situation, resting the staff and preparing for counterattacks. After fast-paced undertakings in discarding the rivals, the staff were exhausted, the speed unable to be maintained continually (McNeilly, 1996). It is a good principle to not fight the battles that cannot be won by direct attack (Chia, 2005). The example of defensive strategy, in Ghazwah Khandaq (Syawwal, 6H), the Prophet built a ditch to protect Madinah from the rival attack (Mubarakpuri, 1996).

\subsubsection{Expansion Strategy}

The ultimate task of Prophet is to do dakwah and spread Islam to all over the globe as the Prophet was titled as Rahmatan lil 'alamin (merciful to all the worlds) by Allah Himself (Qur' an, p. 107). To achieve the mission, this strategy was employed in order to expand the boundary of dakwah area and Islamic influence. Allah SWT said: "And fight in the Way of Allah those who fight you, but transgress not the limits. Truly, Allah likes not the transgressors" (Quran, p. 36). In other verses, Allah SWT said: "And fight them until there is no more Fitnah (disbelief and polytheism: i.e. worshipping others besides Allah) and the religion (worship) will all be for Allah Alone (in the whole of the world). But if they cease (worshipping others besides Allah), then certainly, Allah is All-Seer of what they do. And if they turn away, then know that Allah is your Maula (Patron, Lord, Protector and Supporter, etc.), (what) an Excellent Maula, and (what) an Excellent Helper!” (Quran, pp. 39-40). In addition, Allah said: "March forth, whether you are light (being healthy, young and wealthy) or heavy (being ill, old and poor), strive hard with your wealth and your lives in the Cause of Allah. This is better for you, if you but knew."(Quran, p. 41)

The expansion strategy was used in many battles such as Sariyah Abdullah bin Jahsy (Rajab, 2H) in Nakhlah; Ghazwah Abwa' (Safar. 2H in Abwa: Ghazwah Buwat (Rabi'ul Awwal, 2H) in Buwat; First Badar (Jamadil "Cla. 2H ) in 'C hairah: Ghazah Bani Qainuqa'(Syawwal, 2H) in a part of Madinah; Ghazwah Bani Sulaim (Rajab, 2H) Qarqarah Al-Kudr; Ghazwah Ghatafan (Rabi'ul Awwal, 3H) in Zul Amar; Ghazwah Buhran (Jamadil Ula, 3H) in Buhran; Mission of Zaid Harithah (Jamadil Thani, 3H) Al-Qardah; Ghazwah Hamra' Al-Asad (Syawwal, 3H) in Hamra' Al-Asad; Mission of Abi Salamah bin Abd al- Asad (Muharram, 4H) in Qathan; Ghazwah Bani Nadhir (Rabi'ul Awwal, 4H) in a part of Madinah; Ghazwah Zatul Riqa (Rabi'ul Thani, 4H) in Zatul Riqa; Ghazwah Dumatul Jandal (Rabi'ul Awwal, 5H) Dumah Al-Jandal; Ghazwah Bani Mustaliq (Zil Qa'idah, 5H) Dumah Al-Jandal; Ghazwah Banu Quraizah (Zil Qa'idah, 5H) in a part of Madinah; Sariyah Abu Bakar As-Siddiq (Rajab, 6H) in Wadi Al-Qura; Sariyah Ali bin Abi Talib (Sya'ban, 6H) in Fadk and; Sariyah Abdul Rahman bin Auf (Sya'ban, 6H) in Dumatul Jandal.

\subsubsection{Strategic Flexibility}

The analysis of various strategies has shown that flexibility strategy and principle became the integral part of 
Prophet Muhammad military organization. The flexible strategy is also essential in current companies as the business environments are constantly changing. A word of caution by David (2009), the organization has to beware of becoming of prisoner of its own strategy as every strategy always become outdated. There are a few cases of the Prophet adopted the flexibility strategy such as in Ghazwah Uhud (Syawwal, 3H), the Prophet gave consent to a companion who just converted to Islam to threat the rivals that the Muslims are ready to launch an attack to them. In Ghazwah Ahzab (Syawwal, 3H), the Prophet gave consent to companion to disturb the unity of rival alliances. Besides, in Ghazwah Al-Hudaibiyah (Zul Qa'idah, 6H), the Prophet willing to discard his prior strategy and goal in order to adapt with the environment. Hi prior goal i to perform the urnrah. Whereas, during the siege of Taif $9 \mathrm{H}$, the Prophet learnt that Taif is a very rich city, having many resources. It is not easy and costly to defeat them. The Prophet changed his strategy and called upon his army to depart (Mubarakpuri, 1996; As-Sallabee, 2005; Ahmad, 2005). The flexibility strategy was touched in the Qur'7: Allah said: "And if they (enemy) incline to peace, you incline to peace, you incline to it as well, and put your trust in Allah. Surely He is Most Hearing, Most Knowing." (Qur'an, p. 61).

\subsubsection{Strategic Positioning}

There are a numerous types of strategic positioning from holding the strategic location, technology, patents, unique and profitable products, best and talented personnel. Chia (2005) differentiate the positioning in military and business, in military the positioning is conquering the high ground whilst in business is capturing the high attention of customers mind.

Strategic positioning can be seen clearly when he and the companions migrated to Madinah. The people of Madinah welcomed him, unlike the other place such as Makkah, so the market of his dakwah (calling) is available. In addition, Madinah is not easy to be attacked by rivals, two sides of Madinah are hilly and full of lava blocks in south and west side, plus there are gate gardens in the south area. In east side, there is lava plain. Only on north side has an open space that open to be attacked by the enemies (Rahman, 1980). Furthermore, the Prophet branding the former name of. 1adinah. Yathrib to a new name, that is Madinah Al-Munawwarah which means "the full of light city" (Tubarakpuri, 1996). Regarding the Migrating to Madinah (lH) which is associated with the strategic positioning, there are few Quranic verses mention about the significant event in early Muslim history:

Allah said: Verily! As for those whom the angels take (in death) while they are wronging themselves (as they stayed among the disbelievers even though emigration was obligatory for them), they (angels) say (to them): "In what (condition) were you?" They reply: "We were weak and oppressed on earth." They (angels) say: "Was not the earth of Allah spacious enough for you to emigrate therein?" Such men will find their abode in Hell-What an evil destination! (Quran, p. 97).

He who emigrates (from his home) in the Cause of Allah, will find on earth many dwelling places and plenty to live by. And whosoever leaves his home as an emigrant unto Allah and His Messenger, and death overtakes him, his reward is then surely incumbent upon Allah. And Allah is Ever Oft-Forgiving, Most Merciful (Quran, p. 100).

Those who believed (in the Oneness of Allah-Islamic Monotheism) and emigrated and strove hard and fought in Allah's Cause with their wealth and their lives are far higher in degree with Allah. They are the successful (Quran, p. 20).

So their Lord accepted of them (their supplication and answered them), "Never will I allow to be lost the work of any of you, be he male or female. You are (members) one of another, so those who emigrated and were driven out from their homes, and suffered harm in My Cause, and who fought, and were killed (in My Cause), verily, I will remit from them their evil deeds and admit them into Gardens under which rivers flow (in Paradise); a reward from Allah, and with Allah is the best of rewards."(Quran, p. 195).

The Prophet's chose Madinah to open up new market for his dakwah because of few factors. Firstly, the people of Madinah welcomed him, unlike the other place such as Makkah. So the market of his dakwah is available. Secondly, Madinah is not easy to be attacked by rivals, two sides of Madinah are hilly and full of lava blocks in south and west side, plus there are gate gardens in the south area. In east side, there is lava plain. Only on north side has an open space that open to be attacked by the competitors. Lastly as a strategic positioning, he branding the Yathrib city to a new name, that is Madinah Al-Munawwarah.

\subsubsection{Pre-Emptive Strike}

As the business strategies are stemming from military strategy, pre-emptive strike is military action taken by a 
country in response to a threat from another country or its enemy. The purpose of it is to stop the threatening country from carrying out its threat. The country tried to ward off a perceived offensive or invasion by defeating the enemy before the threat become materialized. Throughout the Sirah, Prophet Muhammad instructed the companion to demolish the mosque built by hypocrites that was used as a place to plan and launch a negative plan to the Muslims. This place and the people associated with it were cursed by Allah in the Qur' an: Allah said: And as for those who put up a mosque by way of harming and disbelief, and to disunite the believers, and as an outpost for those who warred against Allah and His Messenger (Muhammad) aforetime, they will indeed swear that their intention is nothing but good. Allah bears witness that they are certainly liars. Never stand you therein. Verily, the mosque whose foundation was laid from the first day on piety is more worthy that you stand therein (to pray). In it there are men who love to clean and to purify themselves. And Allah loves those who make themselves clean and pure (i.e. who clean their private parts with dust [i.e. to be considered as soap) and water from urine and stools, after answering the call of nature (Quran, pp. 107-108).

In the case of Jews of Khaibar, Khaibar fortresses were used as a place to plan and to launch an attack to Muslims. The Prophet employed the pre-emptive strikes to launch an attack to anticipate the threats of Khaibar Jews (Muharram, 7H). A another application of the strategy is in Ghazwah Bani Mustaliq (Zul Qa'idah, SH), the leader of the Banu Mustaliq or al-Muraisi influenced the people of his tribe and other Arab tribes to fight against Muhammad. The Prophet set out with a small force of his companions and, through continuous and forced marching reached the spring of Muraishi.

In the Battle of Bani Qainuqa' (Syawwal, 2H). As-Sallabee (2005) mentioned that as they found out that the Prophet was marching towards them, they shut down their fortresses. The Prophet's army surrounded them and imposed upon them a siege that lasted for 15 nights. Then they unconditionally surrendered to the Prophet.

In the Battle of Bani Nadhir (Rabi'ul Awwal, 4H); As Bani Nadhir were blatantly violated many articles of their treaty with the Muslims and planned to assassinate the Prophet by dropping the huge stone on him from on top of a wall under which the Prophet was seated. The Muslims army marched towards them and sieges their fortresses. The Prophet ordered for their date-palm trees to be burned down. It is a strategic move because it was their wealth. They began to lose hope and leaded to their defeat.

\subsubsection{Secrecy}

It is challenging to the Prophet to maintain the secrecy by staying together with hypocrites who connected to the Jews and the Quraish. In spite of this, the Prophet did well in keeping the confidentiality and the information about the war planning not often leaked out. Conversely, information regarding the pla1design, strength, weapon and movement of competitor was frequently obtained by the Muslims team (Rahman, 1980). Similar to present day, maintaining the secrecy of plan and design are challenging as the existence of newspaper, websites, blog, YouTube and social media. The confidential information would be leaked out by insiders or outsiders such as employees, ex-employees, journalists, bloggers, researchers and competitor's intelligence. Allah Himself prohibited the Muslims from leaking out and disclosing the news and secrets of the Muslims to the enemy. Allah said: 0 you who believe! Betray not Allah and His Messenger, nor betray knowingly your Amanah (things entrusted to you and all the duties which Allah has ordained for you) (Quran, p. 27).

In Fathul Makkah (Ramadhan 8H), he kept the secrecy of his organization until the threshold of war. No one of his companions knew that he will launch the attack toward his competitor. He surprised the Quraish when he reached Makkah at the head of 10,000 men and caught them unprepared and almost in panic and they yielded without fighting. When he intended to march on Makkah he kept it secret and actually sent one fighting expedition in the opposite direction so that the enemy might be led to think that he was planning to march to Syria. Finally, in Ghazwah Tabuk (Rajab, 9H) speed and secrecy increased the effectiveness of the Prophet's strategy in his mission.

\subsubsection{Low-Cost Strategy}

The scarce resources resulted Prophet Muhammad relied upon unique capabilities to achieve and sustain the low cost position. In the early struggles of the Prophet, the available organization's assets are limited. He strived to develop the team for battles with low cost and low cost distribution system. In Ghazwah Badar (Ramadhan, 2H), the Prophet employed limited of resources; small number of staff and limited transport. The Muslim number was only made up of 300-317. They had only used 2 horses and 3 camels, one for two or three men to ride alternatively. The Prophet himself, Ali and Marthad had only one camel. Prophet Muhammad motivated his companion to sacrifice with spiritual teachings; this makes the companion ready to sacrifice, with their 
belongings and properties. In Ghazwah Uhud, Syawwal 3H, the Prophet had only 700 staff and 100 of them wearing armor.

\subsubsection{Differentiation Strategy}

The religion of Islam sent by Allah SWT to Prophet Muhammad is a unique religion which was succeeded by him from previous prophets. Through this religion the Prophet introduced the new war philosophy, governance or code of conducts and practices which are different from their enemies. The Tawhid (believe of Allah) is strongly bound the companion. The Muslims wage the war because of their faith and believes, not because of their nation, nationality, revenge and detest. Besides, the Prophet and his companions have good reputation in adhering the pact and agreement they have inked. They have higher moral and spiritual that did not own by competitors as they have credible leaders especially the Prophet himself and have the winning mental.

\subsubsection{Focus Strategy}

The of Prophet Muhammad focus his organization in his dakwah (calling) to spread Islam to all over the globe as the Prophet was titled as Rahmatan lil 'alamin' (merciful for all worlds) by Allah Himself (Qur' an, p. 107). Related to Pearce 11 and Robinson (2009), the Prophet's focus strategy was affixed to both the differentiation and low cost strategy. In line to spread the religion, he has to clear up the constraints such as after the Hijrah $(\mathrm{lH})$, he wage the war to Makkah's Quraisy and their alliances to clear up the provocateurs which threatening the Prophet's calling, wage the war to Jews and confront the super powers. Whereas, in Ghazwah Badr (17th Ramadhan 2H), he wage the war to Makkah's Quraisy and their alliances to clear up the provocateurs which threatening the Prophet.

\subsubsection{Blue Ocean Strategy}

Blue Ocean Strategy aim is to create new market space, thereby making competition irrelevant at least for some period of time. The strategy is the simultaneous pursuit of differentiation and low cost. Whereas the conventional Red Ocean Strategy competes in existing market space and out-perform the competition $\mathrm{m}$ existing industry (Kim \& Mauborgne, 2005). The Prophet and companions migrate to Madinah in $1 \mathrm{H}$ in the event of Hijrah as Madinah as a new and still as uncontested market for dahrah. There is a 'market readiness', low people resistance to dakwah of the Prophet no substitute of faith as good as Islam and had political support from majority of Muslim in high attractive market. Another example is Sariyah Abdul Rahman bin Auf (S a "ban 6-Dumatul Jandal as a new and still as uncontested market. A number of people accepted the calling to Islam by Abdul Rahman bin Auf and one of them became his future wife: Tur binti Al-Asbagh or Umrnu Salamah.

\subsubsection{Succession Planning}

Succession planning is a process for identifying and developing internal people with the potential to fill key business leadership position in organization. Succession planning increases the availability of experienced and capable employees that are prepared to assume these roles as they become available. The strategy was utilized in the some occasion for instance in Battle of Mu'tah $(8 \mathrm{H})$. Prophet Muhammad was named three consecutive successors, Zaid bin Harithah was appointed to lead the army. Ja'far bin Abi Talib would replace him in the even if he was killed, and Abdullah bin Rawahah would succeed in the case he was killed.

\subsection{Strategy Implementation, Feedback and Control}

\subsubsection{Strategy Implementation}

One important feature of Islamic practice in decision making is Shura which means decisions are made in joint deliberations and consultation (Ahmad, 2007). On the eve of the battle of Badr the Prophet called his commanders to discuss and plan for the next day's battle. He asked for opinions from companions, except when he receives revelation from God. In order to achieve goals and objectives plans have to be implemented. Leadership is required to direct, coordinate and inspire followers (subordinates). Quran has revealed "Truly, in the Messenger of Allah, you have an excellent example (Quran, p. 21). Ahmad (2007) has summarized Islamic leadership qualities as follow: knowledge and Hikmah (wisdom), taqwa (God-fearing), adl (Gust) and compassion, courage and bravery, decisiveness, eloquence, spirit of self-sacrifice and sabr (patience).

\subsubsection{Espionage and Intelligence}

Espionage or spying involves an organization or individual obtaining information that is considered secret or confidential without the permission of the holder of the information. Espionage is concealed, as it is taken for granted that it is unwelcome and, in many cases illegal and punishable by modern law. On the other hand, intelligence gathering; which is a type of espionage, where information is collected from public sources and 
using perfectly legal and ethical means. The Prophet Muhammad frequently sent the spies to the enemy's camp. In a hadith reported by Jabir: The Prophet, "Who will bring me the information about the enemy on the day (of the battle) of Al-Ahzab (the Confederates)?" Az-Zubair said, "I will." The Prophet said, "Every Prophet had a disciple and my disciple is Az-Zubair."

Conversely, the Prophet always being aware from enemy spies. The hadith narrated 'Ubaidullah bin Abi Rafi: I heard 'Ali saying: "Allah's Apostle sent me, Az-Zubair and Al-Miqdad somewhere saying, "Proceed till you reach Rawdat Khakh. There you will find a lady with a letter. Take the letter from her." So, we set out and our horses ran at full pace till we got at Ar-Rawda where we found the lady and said (to her). Take out the letter. She replied, I have no letter with me. We said, "Either you take out the letter or else we will take off your clothes." So, she took it out of her braid. We brought the letter to Allah's Apostle and it contained a statement from Hatib bin Abi Balta ...

\subsubsection{Risk Management}

The risk management was taken account in strategizing the organization. All types of resources were considered in terms of human, financial, tangible and intangible assets (Kheng-Hor, 2008; McNeilly, 1996). Allah commanded the Muslims to prepare the best skills and resources they can effort to fighting their enemy. Allah said: And make ready against them all you can of power, including teed of war (tanks, planes, missiles, artillery, etc.) to threaten the enemy of Allah and your enemy. And others besides whom, you may not know but whom Allah does know. And whatever you hall spend in the Cause of Allah shall be repaid unto you, and you shall not be treated unjustly (Quran, p. 60).

In another verse: Those who have been expelled from their homes unjustly only because they said: "Our Lord is Allah." For had it not been that Allah checks one set of people by means of another, monasteries, churches, Synagogues, and mosques, wherein the Name of Allah is mentioned much would rule have been pulled down. Verily, Allah will help those who help His (Cause). Truly, Allah is -Strong, All-Mighty. (Quran, p. 40).

The employment of risk management strategy can be seen through the migrating of Prophet Muhammad to Madinah (lH). In early phase after migrating to Madinah, in regard to risk management, the Prophet by inked mutual defence treaty with Jews clans of Madinah (Mubarakpuri, 1996; As-Sallabee, 2005; Ahmad, 2005). It protected the Muslims for short term while they are developing their strength and hindered the Quraish intention of gaining the aid from the Jews. After migrating to Madinah and getting some strength, the Prophet leveraged wars as a way to reduce risk of his organization. Instead of being attacked by enemies, he attacked the enemy first. In addition, every expedition, to minimize risk and ensure the successful of an attack, the Prophet reconnoitered by sending a small intelligence team to attain the latest information as detail as they can about the competitor in terms of numbers of personnel, plan, position, movement and terrain (Rahman, 1980).

In Ghazwah Al-Hudaibiyyah (Zil Qa'idah, 6H), Al-Hudaibiyyah peace treaty was inked by both parties (As-Sallabee, 2005; Ahmad, 2005). The another examples of risk management was applied by Prophet Muhammad such as in Ghazwah Khandaq, being risk management is taken into account, the Prophet instructed of digging of ditch as it is the best option in protecting the Muslims against about triple times of competitors armies. In another case, in Ghazwah Khaibar, he created a security password for his companions, for group of Muhajirun was 'Ya Bani Abdul Rahman', for group of Al-Khazraj was 'Ya Bani Abdullah', for group of Aus was 'Ya Bani Ubaidullah' and for whole Muslims was 'Ya Mansur Amit' (Rahman, 1980).

\subsubsection{Stability and Reinforcement Strategy}

Prophet Muhammad is clearly concerned with the stability and control of organization. This can be seen by stability and reinforcement strategies had been recurred in the Prophet history. Example of expeditions to control and stabilize the country are Sariyah Abdullah bin Jahsy (Rajab, 2H), patrolling Madinah and surrounding area as if there is a threaten from rival, namely Quraish; Ghazwah Bani Qainuqa'(Syawwal, $2 \mathrm{H}$ ), in this expedition to stabilize the market and environment from intervention of rival; Ghazwah Bani Sulaim (Rajab, 2H); Ghazwah Baniiq (Zulhijjah, 2H); Ghazwah Ghatafan (Rabi'ul Awwal, 3H); Ghazwah Buhran (Jamadil Ula, 3H); Mission of Zaid Harithah (Jamadil Thani, 3H); Mission of Abi Salamah bin Abd Al-Assad (Muharram, 4H); Ghazwah Bani Nadhir (Rabi'ul Awwal, 4H); Ghazwah Saul Riqa (Rabi'ul Thani, 4H); Ghazwah Last Badar (Sya'ban, 4H); Ghazwah Bani Mustaliq (Zil Qa'idah, 5H); Ghazwah Bani Quraizah (Zil Qa'idah, 6H); Ghazwah Banu Lihyan (Rabi'ul Awwal, 6H) and Sariyah Zaid bin Harithah (Jamadil Ula, 6H). 


\subsection{Conceptual Framework of the Study}

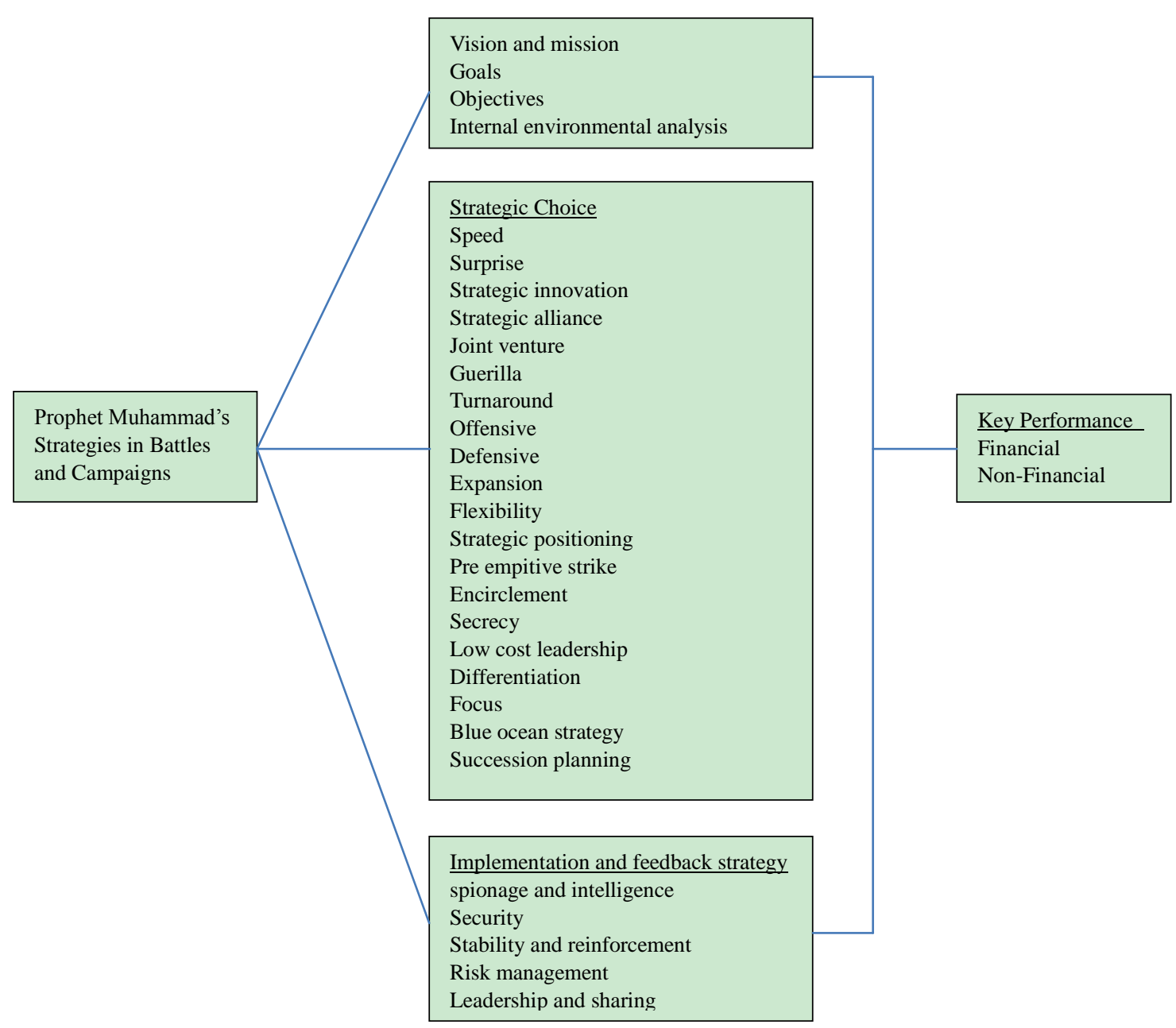

The above framework is rather large to be tackled in a single research project. It may be broken up into a few smaller projects. It is observed that many of the Prophet's strategies were similar to those used by western and Sun Tzu's strategies. The western and Sun Tzu's strategies which have already been researched need not be repeated in this study. The model will be further refined following the interviews with Islamic scholars and the business owners. The priority will be to focus on those strategies and practices of the Prophet which are not yet covered by the conventional researchers. The process of selecting out strategies which are unique to the Prophet will be done in due course and a new and more refined framework will be formulated. Statements of hypotheses will then follow.

\section{Summary}

The purpose of this paper is thoroughly study the biography of beloved Prophet and to recall the Holy Prophet (pbuh) strategies, which he used during his life and mostly implemented in wars and battles for victory. The concept of making strategies is came from Him, which now worldwidly followed by everyone even by Muslims or not Muslims. Prophet presented the thought of environmental Analysis, for the purpose to get information from external and internal environment about enemies. This analysis is applicable upon all organizations especially Military. Prophet always advised His followers to do their work with speed and surprise. And this strategy is now implemented in all organizations to gain competitive advantage. From Ghazwah Ghatafan, Bani Qainuga', Ghazwah Bani Sulaim, Ghazwah Buhran, Ghazwah Last Badar, prophet reffered the offensive strategy, the purpose of this strategy was to take proactive and aggressive action for survival. And now it is practiced to achieve organizational vision and mission of expansion companies have occupy the rivals' territory when 
opportunity permits. With scarce resources Prophet Muhammad relied upon unique capabilities to achieve and sustain the low cost position. In the early struggles of the Prophet, the available organization's assets are limited. He strived to develop the team for battles with low cost and low cost distribution system. From this, low cost strategy is executing in every organization to compete with rivals. To show that your religion is different, and focus upon the vision to spread Islam, He introduced differentiation and focus strategy, and now companies use these strategies for the development of their product with unique attributes and focus on narrow segments to achieve differentiation. After migration to Madinah, Prophet Muhammad, according to the circumstances and the Jews tribes, the Prophet make strategies to reduce risk and take action by gathering the information about the competitor in terms of numbers of personnel, plan, position, movement and landscape. Now it is executed as risk management, to prevent from sudden unfortunate events in future. In short, all the strategies, which are now run-through all organizations are basically belongs to Holy Prophet

\section{References}

A. M. (2005). A biography of the prophet of Islam in the light of the original sources: An analytical study. Riyadh: Maktaba Darussalam.

Ackermann, F., Eden, C., \& Brown, I. (2005). The practice of making strategy: A step-by-step guide. City Road: SAGE.

Addas, W. A . (2010). Methodology of Economics: Secular vs Islamic. Kuala Lumpur: 11UM Press.

Afuah, A. (2009). Strategic innovation: new game strategies for competitive advantage. New York: Routledge.

Ahmed, G. (1986a). The battles of the prophet of Allah. Lahore: Publications Ltd.

Ahmed, G. (1986b). The prophet's concept of war. Lahore: Islamic Book Foundation.

Al-Alwani, T. J. (2006). Islamic thought: an approach to reform: An introduction to the structures of discourse in Islamic thought. (N. Roberts, Trans.) Herndon: The International Institute of Islamic Thought.

Al-Ansari, A. (1961). Tafris al-kurub fi tadbir al-Hurus, a Muslim manual of war. Cairo: The American University At Cairo Press.

Ali, A. C. (1995). Teaching management in the Arab world. International Journal of Education Management, $2-10$.

Ali, M. M. (2010). The History and Philosophy of Islamization of Knowledge. Kuala Lumpur: 1lUM Press.

Alvesson, M., \& Deetz, S. (2000). Doing critical management research. London: Sage Publications Ltd.

Ambrosini, V. (2002). Resource-Based View of the Firm. (Jenkins \& Ambrosini, Eds.). New York: Palgrave Macmillan.

Ambrosini, V., Johnson, G., \& Scholes, K. (1998). Exploring techniques of analysis and evaluation in strategic management. Heartfordshire: Prentice Hall.

Ansoff, I. H. (1984). Implanting strategic management. Prentice Hall.

As-Sa Ilabee, A. M. (2005). The noble life of the prophet. Riyadh: Maktaba Darussalam.

Bahaldin, S. A. (2005). Alternative Quality Management Standards: Islamic Perspective. Kuala Lumpur.

Beekun, R. I. (2006a). Strategic planning and implementation for Islamic organization. USA: International Institute of Islamic Thought.

Beekun, R. I. (2006b). Strategic planning and implementation for Islamic organizations. Herndon: The International Institute of Islamic Thought.

Berghout, A. (2009). Introduction to the Islamic worldview. Kuala Lumpur: 1lUM Press.

Birks, M., \& Mills, J. (2011). Grounded theory: A practical guide. London: Sage Publications Ltd.

Bose, P. (2004). Alexander the great's art of strategy: The timeless leadership lessons of history's greatest empire builder. USA: Gotham Books.

Bruce, A., \& Langdon, K. (2007). Think strategically: Plan the future and make it happen. London: Darling Kindersley Limited.

Bryson, J. M. (2004). Strategic planning for public and nonprofit organizations: A guide to strengthening and sustaining organizational achievement. San Francisco: Jossey-Bass. 
Bryson, J. M., \& Alston, F. K. (2005). Creating and implementing your strategic plan: A workbook for public and nonprofit organizations. San Francisco: Jossey-Bass.

Chakravarti, P. (1993). The Art of War in Ancient India. Delhi: Low Price Publications.

Chapra, M. U. (2001). What is Islamic economics? Jeddah: Islamic Research and Training Institute, Islamic Development Bank.

Charmaz, K. (2006). Constructing grounded theory: A practical guide through qualitative analysis. London: Sage Publications Ltd.

Clausewitz, C. V. (2005). On war. New York: Routledge and Kegan Paul.

Cowley, M., \& Domb, E. (1997). Beyond strategic vision: Effective corporate action with Hoshin planning. Burlington: Butterwrth Heinemen.

Coyle, G. (2004). Practical strategy structural tools and techniques. Harlow: Prentice Hall.

Creswell, J. W. (2009). Research design: Qualititave, quantitative, and mixed methods approaches. Thousand Oaks: Sage Publications, Inc.

Creswell, J. W., \& Clark, V. L. (2008). The mixed methods reader. Thousand Oaks: Sage Publications, Inc.

Creswell, J. W., \& Clark, V. L. (2011). Designing and conducting mixed methods research. Thousand Oaks: Sage Publications, Inc.

Dagnino, G. B., \& Rocco, E. (2009). Cooperation strategy: Theory, experiments and cases. New York: Routledge.

David, F. R. (2009). Strategic Management. Singapore: Pearson.

Dess, G. L. (2008). Strategic Management. Boston: McGraw-Hill.

Doz, Y., \& Kosonen, M. (2008). Fast strategy. Harlow: Wharton School Publishing.

Eisenhardt, K. M., \& Brown, S. L. (1998). Competing on the edge: Strategy as structured chaos. Boston: Harvard Business School Press.

Elkin, P. (1998). Mastering business planning and strategy. London: Thorogood Ltd.

Farhad Analoui, K. A. (2003). Strategic management in small and medium enterprises. London.

Faris, M. A. (1993). Al-madrasah al-nabawiyah al-askariyyah. Cairo: Darul Furqan.

Farooqui, J. (2002). Towards An Islamic Sociology. Kuala Lumpur: llUM Press.

Finkelstein, S., Hambrick, D. C., \& Cannela, J. A. A. (2009). Strategic leadership: Theory and research on executives, top management teams, and boards. New York: Oxford University Press, Inc.

Floyd, S. W., \& Wooldridge, B. (2000). Building strategy from the middle: Re-conceptualizing strategy process. California: Sage Publications, Inc.

Foo, C. T. (2008). The Art of War: System of systems engineering perspectives. Chinese Management Studies, 2(4), 317-326. http://dx.doi.org/10.1108/17506140810910953

Foo, C. T. (2009). Implementing Sun Tzu's art of War, system of systems (SoS) thinking: Integrating pilot's F22 raptor cockpit and the brain of CEO. Chinese Management Studies, 3(3), 178-186. http://dx.doi.org/10.1108/17506140910984041

Foo, C. T., \& Grinyer, P. H. (2010). Sun Tzu on management: The art of war in contemporary business strategy. Singapore: Horizon Books Pte. Ltd.

Franchis, D. (1994). Step-by-step competitive strategy. London: Routledge.

G. A. (1985). The battles of the prophet of Allah. Lahore: Islamic Publications Ltd.

Ghazali, A. (1990). Development an Islamic Perspective. Kuala Lumpur: Pelanduk Publications.

Ghosh, B. C., \& Onn, C. C. (1992). Corporate planning: The practice of corporate planning in small and medium-sized enterprises in Singapore and Malaysia. Petaling Jaya: Pelanduk Publications (M) Sdn Bhd.

Ghyczy, T. V., Oetinger, B. V., \& Bassford, C. (2001). Clausewitz on strategy: Inspiration and insight from a master strategist. (W. Skinner, Trans.) New York: The Boston Consulting Group, Inc. 
Goold, M., \& Quinn, J. J. (1990). Strategic control: Establishing milestones for long-term performance. 1990: Addison-Wesley Publishing Company.

Graham, C. J. (1968). On War General Carl Von Clausewitz. London: Routledge and Keagen Paul.

Grattan, R. F. (2005). Strategy in the Battle of Britain and strategic management theory. Management Decision, 43(10), 1432-1441. http://dx.doi.org/10.1108/00251740510634967

Grattan, R. F. (2006). Robert McNamara's "11 lesson" in the context of theories of strategic management. Journal of Management History, 12(4), 425-438. http://dx.doi.org/10.1108/17511340610692770

Greene, J. C. (2007). Mixed methods in social inquiry. San Francisco: Jossey-Bass.

Greene, R. (2007). The 33 strategies of war. London: Profile Books Ltd.

Griffifth, S. B. (2010). Sun Tzu the art of war. London: Watkins Publishing.

Hai Kee, C. C., \& B. G. (2010). Leadership essentials from Sun Zi's Art of War and the Bhagavad Gita. Journal of Management History, 396-414.

Hamel, G., Prahalad, C., Thomas, H., \& O'neal, D. (1998). Strategic flexibility: Mmanaging in a turbulent environment. West Sussex: John Wiley and Sons.

Haneef, M. A. (2008). A Critical Survey of Islamization of Knowledge. Kuala Lumpur: llUM Press.

Hashim, J. (2009). Islamic revival in human resource management practices among selected Islamic organizations in Malaysia. International Journal of Islamic and Middle Eastern Finance and Management, 2(3), 50-62. http://dx.doi.org/10.1108/17538390910986362

Hashim, M. K. (2007). SMEs in Malaysia: A brief handbook. Petaling Jaya: August Publishing Sdn. Bhd.

Hashim, M. K., \& Wafa, S. A. (2002). Small and Medium-Sized Enterprises in Malaysia. Kuala Lumpur: Prentice Hall.

Hitt, M. A., Freeman, R. E., \& Harrison, J. S. (2005). Handbook of strategic management. Oxford: Blackwell Publishing.

Huczynski, A. (2006). Management gurus. Oxon: Routledge.

Hussain, M. Y. (Ed.). (2006). Islamization of Human Sciences. Kuala Lumpur: Research Centre llUM.

Hussain, M. Y. (Ed.). (2009). Towards Developing an Integrated Research Method in Human Sciences. Kuala Lumpur: llUM Press.

Institute for Community and Peace Studies (PEKKA), UPM. (2006). Muslim religiosity and personality indexing: implications for nation building. Serdang: institute Pengajian Komuniti dan Keamanan (PEKKA), UPM.

Iqbal, A. (2009). The prophet's diplomacy: The art of negotiation as conceived and developed by the prophet of Islam. Delhi: ldarah-1 Adabiyat-1 Delli.

Jacobs, D. (2010). Mapping strategic diversity: Strategic thinking from a variety of perspectives. New York: Routledge.

James, G., Barry, B. (2008). The rules of victory: How to transform chaos and conflict strategies from the art of war. Boston: Shambala Publications. Utusan Publications and Distributors Sdn Bhd.

Jay Conrad Levinson, F. R. (2002). Guerilla publicity. Avon: Adams Media Corporation.

Johnson, G., \& Scholes, K. (1984). Exploring corporate strategy. London: Prentice-Hall International, Inc.

Kaplan, R. S. (1996). The balanced scorecard: Translating strategy into action. Boston: Harvard Business School Press.

Kaplan, R. S., \& Norton, D. P. (2006). Alignment: Using the balanced scorecard to create corporate synergies. Boston: Harvard Business School Press.

Kaplan, R. S., \& Norton, D. P. (2008). The execution premium: Linking strategy to operations for competitive advantage. Boston: Harvard Business Press.

Kaplan, R. S., \& Norton, R. S. (2004). Strategy maps: Converting intangible assets into tangible outcomes. Boston: Harvard Business School Press.

Kaplan, S. R., \& Norton, D. P. (2001). The strategy-focused organization: how balanced scorecard companies 
thrive in the new business environment. Boston: Harvard Business School Press.

Kazmi, A. (2003). Proposed research agenda in Islamic perspectives on management studies. Journal of Economics and management, 11(2), 40-54.

Kazmi, A., \& Ahmad, K. (2006). Management From Islamic Perspective. Kuala Lumpur: 1lUM Research Centre.

Ketchen, D. J., \& Bergh, D. D. (2006). Research Methodology in Strategy and Management. Amsterdam: Elsevier.

Khalifa, A. S. (2001). Towards Islamic foundation of strategic business management. Kuala Lumpur: 11UM Press.

Khaliq Ahmad, F. R. (2011). Management from an Islamic perspective. Kuala Lumpur: Pearson Custom Publishing.

Kheng-Hor, K. (2008). Sun Tzu \& management. Subang Jaya, Selangor, Malaysia: Pelanduk Publications.

Ko, A. S. (2003). Can principles from Sun Tzu's Art of War be used to address of consensus-seeking organizations? Corporate Communication: An International Journal, 8(3), 208-212. http://dx.doi.org/10.1108/13563280310487667

Krause, D. G. (2007). The art of war for executives. USA, New York: A Perigee Books.

L. E., \& B. H. (2011). Performance and risk management in strategic cooperation: A comparative study of business and military sectors. International Journal of Productivity and Performance Management, 60(4), 387-403. http://dx.doi.org/10.1108/17410401111123553

Levinson, J. C. (1993). Guerilla marketing: Secrets for making big profits from your small business. New York: Houghton Mifflin Company.

Liebowitz, J. (2006). Strategic intelligence: Business intelligence, competitive intelligence, and knowledge management. Boca Raton: Auerbach Publications. http://dx.doi.org/10.1201/9781420013900

Lings, M. (1983). Muhammad: His life based on the earliest sources. Rochester, VT: Inner Traditions International.

Lo, V., Ho, C., \& Sculli, D. (1998). The strategic insights of Sun Tzu and quality management. The TQM Magazine, 10(3), 161-168. http://dx.doi.org/10.1108/09544789810214774

Machiavelli, N. (1532/1961). The prince. Harmondsworth: Penguin.

Mahmud Shith Khattab, A. A. (1990). Durus askariyyah min al-sirah al-nabawiyyah. Na: Na.

Manas, J. (2006). Napoleon on project management: Timeless lessons in planning, execution, and leadership. Tennesse, USA: Nelson Business.

Marturano, A., \& Gosling, J. (2008). Leadership: The key concepts. Oxon: Routledge.

Mathur, S. S., \& Kenyon, A. (2001). Creating value: Successful business strategies. Oxford: Butterworth Heinemann.

McKeown, M. (2012). The strategy book. Harlow: Pearson Education Limited.

McNeilly, M. (1996). Sun Tzu and art the art of business: Six strategies principles for managers. New York: Oxford University Press.

Michaelson, G. A. (2010). Sun Tzu the art of war for manager: 50 strategic rules. MA, USA: Adams Media.

Michaelson, G. A., M. S. (2004). Sun Tzu: strategies for marketing. USA: McGraw-Hill.

Mintzberg, H. (2000). The rise and fall of strategic planning. London: Prentice Hall Europe.

Montgomery, W. (1988). Muhammad at Medina. Karachi: Oxford University Press.

Moore, J. I. (1992). Writers on strategy and strategic management: The theory of strategy and the practice of strategic management at enterprise, corporate, business and functional levels. London: Penguin Group.

Mubarakpuri, S. (1996). Ar-Raheeq Al-Makhtum (the sealed nectar). Riyadh: Dar-us Salam Publications.

Naail Mohammed KamiI, M. S. G. (2011). Implications of Taqwa on Citizenship Behaviour. Kuala Lumpur: llUM Press.

Naceur, J. (1994). Islam and management. Riyadh: International Islamic Publishing House. 
Ong Hean-Tat, Y. S. T. (1997). Asian winning strategies for modern \& global business. Kuala Lumpur: Synergy Books International.

Pech, R. J., \& Slade, B. W. (2004). Manoeuvre theory: Business mission analysis process for high intensity conflict. Management Decision, 42(8), 987-1000. http://dx.doi.org/10.1108/00251740410555470

Pech, R. J., \& Slade, B. W. (2005). Business maneuver: Exploiting speed and surprise as key elements. Handbook of Business Strategy, 35-42. http://dx.doi.org/10.1108/08944310510556937

Pettigrew, A., Thomas, H., \& Whittington, R. (2002). Handbook of strategy and management. London: SAGE Publications.

Pheng, L. (2001). Asian wisdom for effective management: From Lao Tzu to Miyamoto Musashi. Kuala Lumpur: Pelanduk Publications.

Porter, M. (1980). Competitive Strategy. Boston: Harvad Press.

Porter, M. (1985). Competitive Advantage. Boston: Harvad Press.

Prahalad, C. K., \& Ramaswamy, V. (2004). The future of competition: Co-creating unique value with customers. Boston: Harvard Business School Press.

Rafik, I., \& Beekun, B. J. (1999). Leadership: An Islamic perspective. Kuala Lumpur: Amana Publications.

Rahman, A. (1990). Muhammad as a military leader. Lahore, Pakistan: Islamic Publications.

Ramli, L. E., \& Osman-Gani, M. A. (2011). Spirituality in Leadership from Islamic Perspectives. (Osman-Gani, $\&$ Mhd Sharif, Eds.). Kuala Lumpur: 1lUM Press.

Rizvi, A. H. (1992). Battles by the prophet. New Delhi: Genuine Publications \& Media Pvt. Ltd.

Robert. (1998). Strategy pure and simple 11: How winning companies dominate their competitors. New York: McGraw-Hill.

Sadeq, M. A. H., \& Ahmad, A. K. (1996). Quality management: Islamic perspectives. Kuala Lumpur: Leeds Publications.

Safi, L. (1996). The Foundation of Knowledge. Kuala Lumpur: llUM Press and international Institute of Islamic Thought.

Salleh, A., \& Ahmad, A. (2008). Human Governance: A Paradigm Shif in Governing Corporations. Kuala Lumpur: MPH Publishing.

Sanghi, S. (2004). The handbook of competency mapping. New Delhi: Response Books.

Schlevogt, K. A. (2002). The art of Chinese management. New York: Oxford University Press.

Silos, L. R. (1998). Management and the Tao. Quezon City: Asian Institute of Management .

Simon, J. L. (2003). The art of empirical investigation. New Jersey: Transaction Publishers.

Singer, A. E. (1996). Strategy as rationality. Hants: Avebury.

Snyder, N. T., \& Duarte, D. L. (2003). Strategic innovation. San Francisco: Jossey-Bass.

Wu, W. Y., Chou, C. H., \& Wu, Y. J. (2004). A study of strategy implementation as expressed through Sun Tzu's principles of war. Industrial Management \& Data Systems, 104(5), 396-448. http://dx.doi.org/10.1108/02635570410537480

Zaccaro, S. J. (2001). The nature of executive leadership: A conceptual and empirical analysis of success. Washington: American Psychological Association. http://dx.doi.org/10.1037/10398-000

\section{Copyrights}

Copyright for this article is retained by the author(s), with first publication rights granted to the journal.

This is an open-access article distributed under the terms and conditions of the Creative Commons Attribution license (http://creativecommons.org/licenses/by/3.0/). 